\title{
Takeover Laws and Financial Development
}

\author{
Tatiana Nenova ${ }^{1}$
}

\begin{abstract}
The issue of "an appropriate" legal framework, especially in the case of the takeover market, has been poorly studied in the case of emerging markets, yet it is of immediate relevance and practical policymaker interest. The study makes a first attempt to analyze takeover regulations in a comparative context across 50 countries. It proposes a methodology to create a detailed index on the most salient features of capital market laws, and illustrates the approach on the case of takeover legislation. The methodology allows better understanding of the impact of laws on markets and development, allows a detailed quantification of a given regulation, in this case takeover market rules, and helps determine relevant policy implications. Specifically, the framework permits the exploration of the effects of individual regulations, their substitutability and interplay, as well as the overall extent of friendliness of the laws to investors, or particular groups thereof (such as minority shareholders), and the links of specialized regulation with the overall legal system. Finally, the study explores the effect of the investorfriendliness of takeover laws on stock market development.
\end{abstract}

\section{World Bank Policy Research Working Paper 4029, October 2006}

The Policy Research Working Paper Series disseminates the findings of work in progress to encourage the exchange of ideas about development issues. An objective of the series is to get the findings out quickly, even if the presentations are less than fully polished. The papers carry the names of the authors and should be cited accordingly. The findings, interpretations, and conclusions expressed in this paper are entirely those of the authors. They do not necessarily represent the view of the World Bank, its Executive Directors, or the countries they represent. Policy Research Working Papers are available online at http:/lecon.worldbank.org.

\footnotetext{
${ }^{1}$ The author would like to thank Simeon Djankov, Alex Berg, Mierta Capaul, Catherine Hickey, Teresa Barger, Mike Lubrano, Stijn Claessens, Vidhi Chhaochharia, Richard Symonds, Claire Grose, and Inessa Love for their comments. Toni Naneva provided excellent research assistance. Tatiana Nenova is a Senior Economist in SASFP, and can be reached at tnenova@worldbank.org.
} 
Capital markets are essential to the growth and development of a country's economy. ${ }^{1}$ First, they channel available funds towards growing businesses (funds may be available from corporate shareholders, domestic and foreign investors, pension funds, banks, insurance companies, or other institutional investors). Second, such markets fill in the gaps left by bank financing, which may not be offered at long maturities and often requires costly and scarce collateral. Equity financing, better than banks, can assume the risk of young fast-growing innovative businesses (such as the challenger airline in Brazil, GOL), which are in need of significant funds, and have grown beyond the self-financing pocket of their owner / entrepreneur, but are too risky for a single bank to finance, and too large for a venture capital firm to engage in. Third, capital markets provide a diversification strategy and growth outlet for key players in a nation's economy, such as pension funds, which can develop only in the presence of a set of markets that would permit their portfolio to reduce risk and reap returns for the beneficiaries.

Capital markets therefore have been a priority focus of national development strategies in the past 15 years. However, past experience shows that promoting a well-functioning and stable capital market that is effective in raising external financing has been an elusive goal for many countries. Policymakers have emphasized the importance of an appropriate regulatory framework to the successful pursuit of a capital markets development strategy. Two studies in the late 1990s first demonstrated convincingly in a cross-country context that laws and financial markets regulation have a tangible and important impact on markets and financial development (La Porta et al 1997, 1998). A veritable flood of research on the impact of laws and regulations on capital markets followed, further deepening our understanding of the area. In addition to cross-country studies, single-country research has been abundant, often focused on the US or UK, and other OECD countries, and recently complemented by research on Brazil, India, and Russia, on a wide range of capital markets topics including corporate control and takeover issues. ${ }^{2}$ Studies confirmed the importance of regulation for development. To name but one example, efficiently functioning legal frameworks were found to encourage firms to use external financing and grow. The literature also uncovered that markets do not react to the promulgated laws, but instead to the first signs of effective enforcement. ${ }^{3}$

Securities and corporate regulations present an entangled body of law which has been hard for academics to quantify in sufficient detail in order to study its impact on development and growth. ${ }^{4}$ As a result, though we know of the overall importance of laws for financial development, it has been difficult for policymakers and researchers alike to draw specific conclusions on the impact of particular legal provisions. One reason for the paucity of crosscountry studies of specific regulations is the sheer complexity of gathering and systematizing the data. The standard approach has been to identify legal provisions and codify them into quantifiable variables, such as the LLSV six-component anti-director index on investor protection. ${ }^{5}$ On acquisition regulation, the sole cross-country index in existence is the Nenova (2001) three-component takeover rules index. The measures of regulations and laws used in such studies are too aggregated, however, and show a general level of legal protection. The measures do not reflect the regulations in detail; rather, they are useful in providing a proxy for the overall quality of capital markets rules. As such, the measures help in showing the importance of regulation and institutions; however, they are less informative on the pros and cons of specific legal mechanisms. Pioneering efforts in delving deeper into the body of law have been provided by World Bank's Doing Business Report, which codifies specific regulations in cooperation with 
legal experts around the world. Topics of focus include company regulations on starting a business, labor laws, contract enforcement, creditor rights and information, bankruptcy, and investor protection, among others. ${ }^{6}$ La Porta, Lopez-de-Silanes, and Shleifer (2006) is perhaps the work using the closest approach to this paper, in that it codifies the securities laws in 49 countries along several dimensions, and uses the newly formed variables to examine the effect of securities laws on stock market development.

This study takes a first step in the above direction by offering a methodology that would fully characterize the set of rules and regulations concerned with changes of corporate control, takeovers, tender offers, and general acquisition activity. Should the methodology prove successful, it is replicable for other facets of capital markets regulation. The framework, allowing a detailed quantification of a given regulation, in this case takeover market rules, permits the exploration of policy implications of the securities laws as they relate to share acquisitions. Specifically, one can explore the effects of individual regulations, their substitutability and interplay, as well as the overall extent of friendliness of the laws to investors, or particular groups thereof (such as minority shareholders), and the links of specialized regulation with the overall legal system. Finally, and most importantly, the methodology permits the study and demonstration of the impact of particular regulations on market development, in particular market breath and depth. This paper does not explore those issues in detail, and focuses instead on presenting the methodology and general uses of the new data; detailed exploration on specific regulations is relegated to further research. The issue of "an appropriate" legal framework, especially in the case of the takeover market, has been poorly studied in the case of emerging markets, yet it is of immediate relevance and practical interest, in particular in Latin America, East and South Asia, and Central Europe.

The literature exploring takeovers issues is extensive, and recent overviews are presented in Burkart and Panunzi (2006), Andrade, Mitchell and Stafford (2001), Bhagat, Shleifer and Vishny (1990), among others. Relevant literature is cited further along in the paper, as specific topics are discussed, e.g. mandatory offers or going private deals.

\section{The market for corporate control}

Corporate control transactions occur for several reasons. First, in the natural growth cycle of a company, the original entrepreneur may find his brainchild grown beyond the proportions of a small one-owner firm. Due to the need for additional financing, professional management, organizational complexity, costs of running the business, diversification motives, or any other idiosyncratic cause, the main owner may want to sell control of the company. Second, and related, the descendants of the original founder may wish to sever their ties with the family company, because there are succession issues, or the family is distanced from effective company management and does not feel comfortable with the risk exposure without commensurate control, so as to prefer to diversify their financial holdings into investments that would lower their overall risk of value loss. Control may also be sold to a multinational company, which brings in the know-how, marketing, and distribution channels that are inaccessible to a standalone firm. In countries with less concentrated ownership, control can be claimed in a hostile 
attempt, by a bidder who believes that company value can be enhanced. Friendly or hostile deals can also be executed for reasons of expected synergies between the acquirer and target.

Takeover laws are concerned with the orderly process of changes in control, their transparent conduct, equal opportunities for all investors, and "fair" treatment of all existing shareholders. Control is defined here conventionally as influence over corporate decision-making via a given number of votes in a general assembly. ${ }^{2}$ Typical takeover laws require that any sizeable purchases of stock in a corporation be made via a tender offer (as opposed to open-market operations), on equal terms to all tendering shareholders, with any excess shares offered being pro-rated, so that every tendering investor has the same proportional chance of selling their shares to the bidder. Other elements of a takeover law would include fairness provisions on taking the company private, rules on equitable treatment of shareholders, as well as disclosure regulations. The law would also have a set of fairly intricate procedural steps and deadlines for the carrying-out of the tender offer itself. The use of anti-takeover tactics could also be limited in takeover regulations (a detailed example of a takeover law on the case of Chile is presented in Section 3). Specific characteristics of takeover laws are discussed in the Section 4.

Takeover regulation stands to resolve several major objectives, and different countries have in practice selected various solutions to these issues:

Objective 1: Allow companies to defend themselves. The optimal extent to which policymakers believe companies should be allowed to protect themselves against takeovers varies considerably. Defenders of a laissez-faire approach have adopted minimal takeover protection, in the belief that a company whose value may be improved by an outsider should become subject to such an improvement. The opposing view is that short-term value improvements may be detrimental to both the long-term stability of the company as well as other social goals important to policymakers, such as employee welfare, and therefore companies are allowed a considerable set of anti-takeover mechanisms in the law. The resolution of this issue in the legislative field is intimately related to the frequency of corporate control transactions in the capital markets.

Objective 2: Perform a "sentinel" corporate governance function. When a company is found undervalued, or "cheap" relative to what it could potentially be worth if it was run better, a corporate raider should find it profitable to purchase it, turn it around, and re-sell it at profit. Evidence is plentiful that takeovers address governance problems. ${ }^{7}$ On the other hand, changes in corporate control have been criticized as an effective governance mechanism due to the freerider problem, the danger of overpaying for the target company, and the exorbitant takeover cost which makes acquisitions useful only in correcting more serious governance problems. ${ }^{8}$

Objective 3: Ensure the fair division of value between controlling parties and minority investors. What is the appropriate definition of "fair" in this case? Fairness does not necessarily imply equal price. For one, controlling parties face costs of maintaining control that minority

\footnotetext{
${ }^{2}$ Control can be embodied in a high level of ownership, veto rights, golden shares, board control, etc. The EU Directive on Takeover Binds, for example, leaves the definition of control to the member states. The most standard legalistic definition, also used for research purposes, is in fact possession or use of over $20 \%$ to $50 \%$ of the voting rights. This paper uses the specific percentage of votes as legislated in each country to form a variable and explore the effects of this provision on financial market development.
} 
investors do not face. They have most of their wealth concentrated in their large stake in the firm stock, whereas other shareholders (such as pension funds) are well diversified. Further, controllers face fiduciary duties, the threat of lawsuits, etc. On the other hand, they may obtain benefits not available to the common investor, as well.

In discussing the fair division of corporate value among all takeover participants, it is useful to gain an idea of the magnitude of value available for distribution. Research shows that the value to be redistributed in takeovers, referred to as "control premium", can be considerable. The control premium can reach $29 \%$ in Italy, and $20 \%$ in Switzerland. In contrast, it is less than 10\% in Japan, Germany, UK and US, to name but a few countries. The control premium is potentially higher in emerging economies, where markets are less complete. It is 58\% in the Czech Republic, 27\% in Argentina, Colombia, and Venezuela, 48\% in Korea, and 36\% in Mexico. ${ }^{9}$

The issue of fair treatment of market participants involved in the takeover has been defined and resolved in a widely divergent manner in different countries. In France, the corporate owner and the minority shareholders receive the same price. In Brazil, before 1999 the sale price of control was not publicly disclosed, and minority shareholders did not share any takeover gains (estimated at around $25 \%$ of company value). ${ }^{10}$ Sharing value with minority investors makes takeovers expensive, so they occur more rarely. The lower takeover threat could cause negligent managers to "relax" and fail to maximize company value. On the other hand, not sharing any value with minority shareholders may rob them from one of the few opportunities to receive a return on their investment, especially in less dynamic markets where dividends and capital gains are not abundant.

\section{Investor protection during takeovers and market development}

National legislations resolve in various ways the three objectives of takeover laws, and these policy choices affect the depth and breath of capital markets, and the willingness of minority investors to participate in the market. In addition to the effect of the laws, poor law enforcement further discourages stock market activity and development. ${ }^{11}$ Appendix A presents a simple theoretical example that helps appreciate the validity of this argument.

The argument is not specific to takeover rules, and can equally well be applied to other securities laws. The appendix posits the following hypothesis: Breadth and depth of stock markets decrease with poorer investor protection, in particular with poorer protection of investor returns during takeovers. This hypothesis has been tested and confirmed in the case of several investor protection variables, as well as some acquisition-related variables. One example is Rossi and Volpin (2004) who find that countries with better investor protection have more takeovers, and more hostile deals, the latter explained by the fact that control is also less contestable in countries with low investor protection. ${ }^{12}$ They also find that countries with lower investor protection experience more cross-border takeovers, and the volume of cross-border takeover activity increases with the difference in investor protection quality between countries. 


\section{The useful minority protections of a typical takeover law - the case of Chile ${ }^{13}$}

During the 1990s, a wave of changes of control occurred in Chile through private transactions at prices that were $70 \%$ higher on average. Minority shareholders did not participate in this upside. Shareholder dissatisfaction peaked during the takeover of Enersis S.A, Chile's largest private energy conglomerate, by Endesa España (Spain) in 1997. The deal became a landmark case in minority shareholder rights and equitable treatment and prompted the overhaul of Chilean takeover legislation. The case also allows a simple illustration of the rules which would prevent minority rights abuse, as well as a practical view on the exact functioning of different protection mechanisms.

Enersis was controlled by a group of five investment companies, known as the Chispas, via 29.04\%. All Chispas companies had the same political structure: class A shares had $99.94 \%$ of the ownership and elected 4 out of 9 directors (held by pension funds); and Class B shares that represented $0.06 \%$ of the ownership but elected 5 out of 9 members of the board (held by Enersis management). Had the country been under a one-share-one vote listing rule, the expropriation of non-voting shareholders (in this case the pension funds and ultimately their retired beneficiaries) would not have occurred.

Even with barely $30 \%$, the Chispas controlled Enersis due to its diluted ownership structure. The takeover was preceded by secret negotiations between Endesa Spain and key executives of Enersis S.A, who were promised a handsome price premium in exchange for cooperation on the takeover. Endesa España offered USD 253.34 for each B share and only USD 0.30 for the A shares. A takeover legislation with an equal-pricing rule would have made the deal impossible. The Spanish company also offered Class B shareholders the option of purchasing up to $5 \%$ of Endesa shares at discounted prices, and guaranteed the Enersis managers their positions for at least five years. Strict adherence to good disclosure practices would have revealed this information prior to the tender offer and publicized it, likely increasing the chances for a public outcry prior to the deal. Moreover, Enersis executives would be considered as acting in concert with Endesa España, and therefore the notice would require that they state their intentions to collaborate in a change in control, as well as the sweeteners used by Endesa España to lure their cooperation.

Enersis executives applied pressure and influence to encourage employees to sell their shares. In October of that year, details of the acquisition strategy were made public by the press, because Endesa España, which was publicly traded in both the US and Spain, had filed several documents with the U.S. SEC and the Spanish CNMV, explaining the terms of an agreement between Endesa Spain and the Enersis executives. It was only at this point that the Chilean minority shareholders, the pension funds, became aware of the details and decried the planned deal. Had that not happened in time, the pension funds would have been left with non-voting shares and no control over Enersis, which would have gone under the complete control of Endesa España. Had the latter considered taking Enersis private, the pension funds would have lost virtually all value of their shares, an expropriation which will be fully avoided with the new Chilean takeover law, which does not allow squeeze-outs and gives dissenting shareholders appraisal rights in this case. 
The new law ${ }^{14}$ established that share transactions that result in a person's or group's acquisition of control of a corporation must be conducted through a tender offer. Additionally, when the target company has several classes of shares with different voting rights, the tender must be extended to all classes in proportion. Partial offers must be pro-rated. ${ }^{15}$ The law also contains a mandatory offer provision, so that a shareholder who reaches the ownership level of $2 / 3^{\text {rds }}$ of a corporation must tender for all outstanding shares and classes. An optional transitory rule shielded companies for a further three years from the new law, to allow learning, and most firms took advantage of that rule. The details of the law are presented in Appendix C. The securities regulator (Conasev) can enforce takeover law by issuing additional rules, imposing fines for noncompliance, demanding complete information about the transaction, and suspending tender offers procedures, even before they have started, in response to incomplete disclosure or a legal obligation default.

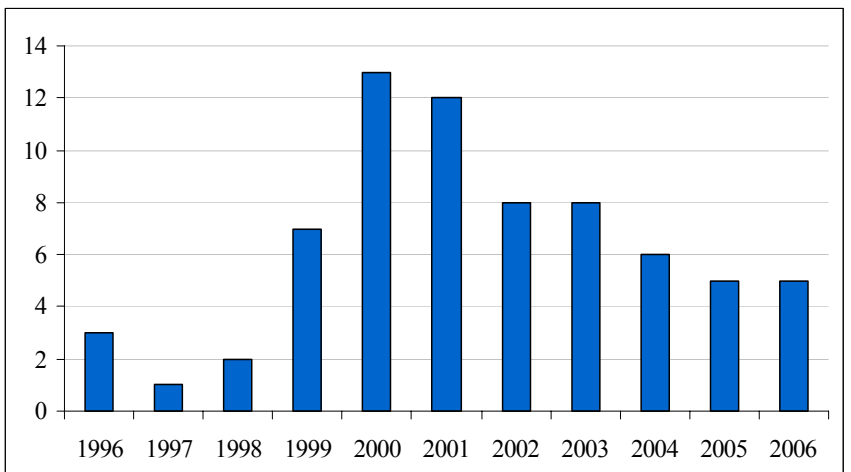

Figure 1. Annual takeovers in Chile
Following the implementation and enforcement of the new law, in 2000 and thereafter, one can note a new wave of IPOs on the Chilean stock market, and a healthy trend of takeover activity after the reform. The average number of takeovers has increased after year 2000 (see figure 1). The control premium paid over market prices, $23 \%$, is now shared more equally between controlling shareholders and minorities. 


\section{Review of the components of takeover laws}

The UK City Code on Takeovers and Mergers is an example of a best practice takeover regulation. Its main features are a mandatory takeover bid at 30\%, at the highest price of the past 12 months. All classes, including non-voting shares, must be included in the mandatory offer. The bid must be extended to any willing shareholders post factum, at the same terms. Cash must be offered as an option in certain cases. Disclosure rules pre- and during the offer are strict; ownership is reported upon acquiring $3 \%$ of any class; intentions to take control at $15 \%$, and to take the company private at $30 \%$. Sell-out rules are available at $90 \%$, at a fair market price, and there is an oppressed minority protection mechanism through the court. The takeover rules apply to all public companies, not only those that are listed. Finally, anti-takeover actions are only allowed with shareholder approval (General Principle 7, Rule 21, City Code). The European Commission Directive on takeovers makes an attempt to unify European legislation (see Appendix B). Following the review of the law components and the index we form, we present the US example, which stands in contrast to the UK and EU approaches. At the other end of the spectrum, we have the emerging markets where no detailed takeover regulations exist, such as Azerbaijan, Ecuador, and Uruguay. One could count upward of 20 countries with stock markets where no basic tender offer regulations exist. This section overviews the main elements of takeover laws illustrating them with examples from various national legislations.

\subsection{Early warning}

One early signal available to investors about potential parties interested in control is to look at significant existing owners of the corporation. Typical disclosure rules provide for ownership thresholds which, when crossed, trigger an obligation to disclose certain information and possibly, their intentions to gain control. In most countries, the lowest threshold for ownership disclosure is $5 \%$, and lower (or continuous) ones may be provided for board and management. Such disclosure is typically "in real time", i.e. within days of crossing the threshold, e.g. 7 days in Nigeria. The disclosure is usually to the securities regulator and the stock exchange, which in turn make it public. The onus of disclosure could fall on the company, or on the shareholder. In France, in addition to ownership disclosure triggered by crossing of certain thresholds $(5 \%, 10 \%$, $20 \%, 33.3 \%, 50 \%$ or $66.7 \%$ ), the company can call for the disclosure of all holdings of at least $0.5 \%$ of the capital by making such provisions in its articles of incorporation.

The index component we form is defined as follows: ${ }^{16}$

- Range where intention to control is known - the range where the intention of a shareholder to gain control of the company is publicly known. It varies between 0.50 in countries where prior disclosure of control intentions is not mandated (e.g. Egypt), to 0.95 in Brazil and Philippines, for example, where the intention to gain control must be disclosed at $5 \%$ of ownership and thereafter.

\subsection{Mandatory offers}

Mandatory offer rules oblige a large shareholder to bid for the company shares after reaching a certain level of ownership. Tenders must be for all outstanding shares - the bidder cannot limit the shares s/he stands ready to buy. Also in contrast to general tender offers, mandatory offers generally cannot be conditional upon a certain percentage of shareholders accepting the offer. 
Mandatory offer rules serve to protect minority shareholders from inefficient control transfers, as repeatedly shown in the academic literature, but also decrease the chance that efficient control transfers occur. ${ }^{17}$ Beyond the positive effect of the mandatory offer rule on minority rights, there have been no studies on the optimal ownership threshold at which an offer becomes mandatory. To the extent that a lower mandatory offer threshold increases the incidence of sharing the control premium with minority shareholders, we expect a negative relationship between the mandatory offer threshold and better minority shareholders rights. A more conservative approach would limit itself to assuming that the presence of a mandatory offer rule improves minority rights, and shy away from any assumptions on the effect of the threshold level. We repeat all tests using this alternative approach which captures the mandatory offer component as an indicator dummy instead of a continuous threshold variable.

Mandatory offer thresholds can vary widely, from 15\% for India and 25\% for Ghana, to $67 \%$ for Finland. In this approach, general tender offer rules are left quite liberal, at the choice of the bidder structuring the offer. More than half the sample (27 countries) complies with this pattern. Some countries could be added to this list, who have no mandatory offer rules, but whose tender offer regulations nevertheless provide a mechanism to extend the terms of a general tender offer to all shareholders who would be wiling to sell but couldn't during the offer (be that because they were pro-rated, or because they decided to tender only after seeing the offer results).

In Latin America (Colombia, Peru) and the Middle East -North Africa (Egypt, Jordan), the law frequently provides for partial mandatory tender offers (e.g. a mandatory offer at $25 \%$ of ownership, for at least $5 \%$ of the shares), thus effectively excluding from the process some shareholders that may be willing to tender their shares. ${ }^{18}$ These cases are coded as not having an effective mandatory offer rule. To that list, one could also add the countries where no tender offer regulations have been adopted yet.

Most countries allow block trading of securities off-exchange, by private negotiation. In Argentina, for example, there is no disclosure on off-market deals. As a result, minority shareholders cannot share any of the value from control changes, as there is simply no information on the control change premium from deals arranged behind closed doors. In Brazil, in contrast, both on- and off-exchange transactions with listed securities must be disclosed to the securities regulator, including the price. In Lithuania, off-exchange trading of listed securities is banned altogether.

In certain, mainly developed, countries, tender offer and going private rules apply to non-listed companies as well as listed ones. This provision extends minority protection beyond stock exchange investors, to small shareholders in general. Due to the challenges of effective enforcement of this provision, few emerging markets can afford to implement it.

The index component we form are defined as follows:

- Mandatory offer range - the range of ownership where the shareholder is mandated to tender to all shareholders (mandatory offer), even if s/he does not want to acquire additional shares. In the absence of mandatory offer rules in the country, we look at the tender offer regulations. If the latter mandate a tender offer to all existing shareholders upon crossing a certain ownership level, and if non-tendering 
shareholders can sell their shares at the same price after the offer has ended, we consider such rules equivalent for the purposes of minority protection, to a mandatory offer regulation in the given range. For example, there is a mandatory offer rule in India at $15 \%$ of ownership, so the variable takes the value of 0.85 . As another example, consider the case of Canada (Ontario laws), where no mandatory offer rule exists, but acquisitions of $20 \%$ or more must be made via a tender offer. Following such an offer, all shareholders who want their shares purchased have the right to sell them subsequently, at the tender offer price. In this case, the variable takes the value of 0.80. In general, the mandatory offer range variable takes values from 0 in countries such as Armenia, where no mandatory offer rules exist, to 0.95 in Korea, where tender offers must be made if the bidder purchases from more than 10 shareholders, and if the intended ownership level acquired would exceed $5 \%$.

- Off-exchange price disclosed - The variable takes the value of 1 if the price at which off-market deals are concluded is publicly disclosed or if off-market trading is forbidden for listed securities, 0 otherwise. More than half of the countries have this provision.

- Rules apply to non-listed firms - The variable takes the value of 1 if any public offer rules (rules for mandatory or partial offers, or taking private rules) apply to non-listed firms, 0 otherwise. Less than one third of the countries have such provisions.

\subsection{Pricing of tender offers}

Most mandatory offer rules prescribe a minimum price that the bidder must offer. This is typically some average of past market prices, and serves as a protection against bidders underpaying for securities relative to their fair market value. The concept of "fair" is defined in the national law and would vary across countries. For example, the law provides for the minimum tender offer price in Bulgaria to be the higher of (1) the average weighted market price for the past 3 months, and (2) the fair value as assessed in the prospectus documents. In some countries, the law recognizes that due to market illiquidity, the market price may not reflect the underlying company value, and therefore prescribes that the fair price for the purpose of the tender offer should be determined as the higher of the book value and past market prices. Some countries may restrict the offer consideration to cash only, but generally, an offer is allowed in exchange for cash or other (usually easy to value) securities. ${ }^{19}$

A step further is to extend investor protection to shareholders holding shares with limited or no voting rights, and mandate that they be included in the tender offer, or even at some measure of a "fair" price that the law may provide. For example, in South Africa the mandatory offer is to the holders of any class of equity capital (voting or non-voting) and to the holders of any class of voting non-equity capital to acquire their securities for the same or comparable consideration. ${ }^{20}$ Pakistan, by dint of having a single class of shares, achieves the same effect of minority protection without the need for a specific rule in its takeover regulations. Fair pricing between classes is a very costly provision for bidders, and is likely to reduce, if not stifle, the takeover market; as a result, only countries with very active stock markets have instituted such a provision. 
The variables we form are defined as follows:

- Fair price for minority - The variable equals 1 if the mandatory offer (or tender offer, in the absence of mandatory offer rules by law) is restricted by law to specify a price at least above some measure of past market prices, 0 otherwise.

- Fair price for all classes - The variable equals 1 if the mandatory offer (or tender offer, in the absence of mandatory offer rules by law) is restricted by law to include all classes (including non-voting shares) at a comparable ("fair") price by any legal definition that the country laws provide, or if by law companies are constrained to have only one class of shares listed; 0 otherwise.

\subsection{Tender offer notice}

Disclosure during a tender offer is one of the vitally necessary conditions for takeover laws to function properly and be effectively enforced. There is a dearth of empirical evidence on the effect of tender offer disclosure; however the literature abounds with data showing the positive effect of disclosure and transparency in general on listed companies. ${ }^{21}$ Tender offer disclosure mainly consists of the public notice announcing the tender offer terms and conditions, any disclosure during the offer on changes of terms or competing offers, as well as an announcement of the offer results. The tender offer notice is usually published in the business or official press as well as filed with the regulator, together with the offer documentation (the prospectus). ${ }^{22}$

Two further elements of disclosure are important for the smooth functioning of the tender offer. First, the bidder needs to be able to obtain a full and up-to-date list of the target's shareholders, promptly after announcing intentions to make a tender offer. Second, the board of directors of the target company may be mandated to express a public opinion on the desirability of the offer for the target shareholders.

Nearly all countries with tender offer rules provide basic prospectus information such as the identity of the bidder (that also depends on the quality of ownership disclosure) and bidder financial information.

Table 1

Disclosure in tender offer prospectus

\begin{tabular}{|l|l|}
\hline $\begin{array}{l}\text { Very incomplete } \\
\text { or non existent }\end{array}$ & $\begin{array}{l}\text { Armenia, Azerbaijan, China, } \\
\text { Colombia, Ecuador, Egypt, } \\
\text { Jordan, Peru, Uruguay }\end{array}$ \\
\hline & $\begin{array}{l}\text { Argentina, Czech Republic, } \\
\text { Ghana, India, Indonesia, Nigeria, } \\
\text { Incomplete }\end{array}$ \\
\hline & $\begin{array}{l}\text { Austria, Turkey } \\
\text { Finland. Korea, Lithuania. Bulgaria, Chile, } \\
\text { Malaysia, Mexico, Philippines, } \\
\text { Poland, Sri Lanka }\end{array}$ \\
\hline & $\begin{array}{l}\text { Brazil, France, Germany, Greece, } \\
\text { Israel, Italy, Kenya, South Africa, } \\
\text { Switzerland }\end{array}$ \\
\hline \multirow{5}{*}{ Detailed } & $\begin{array}{l}\text { Australia, Canada, Hong Kong, } \\
\text { Japan, Netherlands, Singapore, } \\
\text { Very detailed }\end{array}$ \\
\hline
\end{tabular}

Of course, all laws mandate the mention of the offer terms and conditions, such as the number of shares and the price, whether the offer is conditional or partial, date of start and end of offer, and the broker managing the process. There is wide divergence, however, among countries when one focuses attention on further disclosure beyond basics. Table 1 divides countries in disclosure categories, according to four disclosure criteria that go beyond basic prospectus information (see the index definition below).

The variable we form, the mandatory offer disclosure index, is a simple average of four $0 / 1$ indicators of whether the following disclosures are required in the tender offer prospectus for 
a mandatory offer or not. In the absence of mandatory offer rules, the variable refers to any tender offer rules provided by law, and takes the value of 0 if no such rules exist. The components are:
- past contracts, transactions and agreements between acquirer and target;
- estimated consequences to bidder's shareholders (if a corporation);
a target board opinion;
a proof of sources of financing for the offer.

\subsection{Tender offer procedure, rules applicable following the offer, and aggrieved shareholder recourse}

In order to prevent formation of a fake market for the target shares and to protect the interests of the minority shareholders of the target company, once the offer has been publicly announced, the law prescribes short time limits prior to the start of the offer, such as deadlines for filing the offer document with and inspection from the authorities, publications and notifications. ${ }^{23}$ It is important for the smooth functioning and stability of the control market that the bid be firm and not subject to change. ${ }^{24}$ Typically, tendered shares need to be deposited with the broker or the central depository institution, in which case it becomes important that the law clearly determines the date when the tender transaction becomes final. ${ }^{25}$ Typically, bidders are prohibited from purchasing shares on the stock exchange during the tender offer acceptance period. ${ }^{26}$ Following the conclusion of the offer, the bidder discloses the number of shares tendered, the number of shares acquired, the pro rata factor if applicable, and the ownership share achieved as a result of the offer, within a certain time prescribed by the law. The law may limit further post-offer acquisitions, tender offers, or even open market purchases by the bidder, in order to assure equal treatment to all shareholders. $^{27}$

A popular minority protection is the right to sell one's shares at the tender offer price, even after the end of the tender offer period. A little less than a third of all countries offer this right to investors. Such a protection, effectively playing the role of an "appraisal right" in the limited case of tender offers, permits shareholders to wait and see the final offer result before they decide whether to withdraw from the corporation. ${ }^{28}$

More generally, the appraisal right rule is an important investor protection mechanism that most national legislatures provide for, following major corporate decisions. It allows aggrieved/ dissenting shareholders to sell their shares back to the corporation after fundamental changes in the company, such as the change in control, a merger, a going private decision, change in the nature of the business or the company deeds, etc. Appraisal rights specifically following a merger are mandated in about half of the countries studied. It is important to provide for a "fair" price at which appraisal rights are exercised, usually based on an average of past market prices. ${ }^{29}$ About one-third of the countries legislate fair pricing. An even more powerful mechanism which addresses aggrieved shareholder issues is the oppressed minority recourse. ${ }^{30}$

Since tender offer procedure rules are fairly uniform across countries, we do not code any variables on procedure. The variables we form are defined as follows: 
- Fair price for non-tendering investors - The variable equals 1 if shareholders who did not tender during the term of the offer have the right for a given period after the offer to be bought out at the same terms, 0 otherwise.

- Appraisal rights after a merger - The variable equals 1 if appraisal rights are available, at market or otherwise "fair" price, to shareholders who abstained or dissented from a merger at the annual shareholder meeting where the merger was approved; 0 if appraisal rights are available at book value, or the law does not specify the price, or if appraisal rights are altogether unavailable by law, even if an oppressed minority redress mechanism is available in the country. ${ }^{31}$

\subsection{Rules for taking the company private}

Taking private regulations typically involve a certain threshold of approval by the general shareholder meeting (e.g. $75 \%$ as in Nigeria). Not infrequently, the market for company shares is weak at this level of ownership concentration, and there is a supermajority owner. The $25 \%$ minority shareholders have very little effect on corporate decisions, if any. In order to assure their fair treatment, the law makes elaborate provisions for taking the company private. In certain cases, such a procedure needs to be carried out via a public tender offer, where all national tender offer regulations fully apply (e.g. in Malaysia). Related rules provide for the right of shareholders to require the super-majority owner to buy their shares "a sell-out right", usually at a level of ownership around 90\%. The price of such sell-out rights may be determined by the law, and may be based on some definition of fair valuation. ${ }^{32}$ Sell-out rights are found to have a positive effect on efficiency and minority interests. $^{33}$

The variables we form are defined as follows:

- Range where intention to take private is known - the range where the intention of a shareholder to take the company private is publicly known. It varies between 0 in countries with no such disclosure (e.g. Jordan and Ecuador), to $95 \%$ in countries such as the USA, where at $5 \%$ ownership disclosure shareholders must state their intentions (if any) to acquire control or take the company private.

- Sell-out provisions - the variable takes the value of 1 if minority shareholders can require the majority owner to buy them out at a certain level of ownership (usually $90 \%$ or more), and the law provides for some measure of a market ("fair") price for the sell-out; 0 if sell-out rights exist at book value or no price is specified in the law, or such rights are not regulated by law at all.

\subsection{Allowable anti-takeover mechanisms}

Perhaps the most notorious tactic has become the poison pill, though it is by far not the most commonly used one around the world. ${ }^{34}$ Some of the more exotic tactics include greenmail, litigation, Pac man defense, scorched-earth, safe harbor, and golden parachutes. One of the 
most benign tactics allowed by law in virtually all countries around the world is a negotiation with an alternative friendly acquirer - white knight or white squire. ${ }^{35}$ Poison pills and other sophisticated defenses are popular almost nowhere outside of the US, and are especially rare in emerging and in less active markets. In some countries, they are simply not needed, as less sophisticated defenses to takeover exist, e.g. Argentina and Switzerland. In others, general liability provisions, equal treatment rules, and duties to act in the interest of the company may render poison pills unacceptable, even if they are not outlawed, e.g. Austria and Brazil. ${ }^{36}$ For example, in Turkey, the average listed company is family-controlled at the $80 \%$ level. $^{37}$ In such cases, concentrated ownership replaces effectively any and all other anti-takeover defenses. In cases where companies still feel vulnerable to a hostile attack, other simple anti-takeover tactics have been used, such as limitations in outsider governance powers or defensive corporate control structures.

A company could undertake many fully legal actions that would reduce its attractiveness. In this case, shareholders lose the opportunity to consider the tender offer and perhaps benefit from it. To the extent that hostile bids can offer a higher value to minority shareholders, as a vast body of literature shows, ${ }^{38}$ they are beneficial for investors, and should not be fended off by a defensive management or a large shareholder. For that reason, takeover codes may ban all actions that frustrate a takeover offer (a blanket prohibition), or enumerate specific bans on corporate defense actions, allowing them only with general shareholder approval. Such rules may nevertheless fail to stall anti-takeover defenses adopted well in advance of an actual takeover threat, since the law does not subject preventive defenses to the clearance of current shareholders at the time of takeover. ${ }^{39}$ That could hurt minority interests by lowering the incidence of control changes, as the case of France illustrates. ${ }^{40}$

There are several approaches to limiting anti-takeover efforts. The most fool-proof legal limitations stem from director liability, equal treatment, and minority oppression rules. A classic example is the UK City Code. ${ }^{41}$ The filter is so strict that in practice only "white knight" tactics are allowed as a defense against hostile takeovers (Canada and Singapore are examples here). ${ }^{42}$ Fiduciary provisions may be less effective in countries with a weak judiciary. The alternative approach of clear-cut legislative bans on specific defensive actions may be more effectively enforceable in countries where courts are slow and lack specialization. $^{43}$

In part, the difficulty of limiting anti-takeover tactics in practice is the multiplicity of mechanisms that can be used, as well as the constant creativity of companies in fashioning new ones. We review below some common tactics that have proven to be most frequently encountered in a mix of vibrant and underdeveloped capital markets and legal environments.

\subsubsection{Defensive recapitalizations and changes of the asset structure}

One way for a company to avoid a takeover is to make a major change in its capital structure. For example, the company can issue large volumes of debt, buy back shares, ${ }^{44}$ or go private through a leveraged buy out. Alternatively, the target company can issue more stock, making it more expensive for the acquirer to gain control, as this requires the purchase of more shares as compared to before the share issue. Typically, defensive share issues during a 
takeover are only allowed with shareholder approval, as in Singapore, and India. ${ }^{45}$ Some countries outright forbid such issues, as Bulgaria. ${ }^{46}$

Finally, the target company can sell off assets and render itself less attractive to the acquirer. Typically, the law prescribes prior shareholder approval of material asset sales. Such approval rule exists at all times (e.g., shareholders approve all sales of at least $20 \%$ or $50 \%$ of assets). In the presence of a takeover threat, the threshold may be lower. ${ }^{47}$ A little less than half of the sample countries either forbid share issues and asset sales during a takeover, or require shareholder approval.

\subsubsection{Defensive limitations in governance powers}

A potential acquirer can be discouraged by "crippling" his/her ability to govern the company even after a majority of the shares have been acquired. One example of such tactics is voting rights, or limitations on the amount of votes a given shareholder can cast (irrespective of their level of share ownership). Those are present in $56 \%$ of the sample countries. ${ }^{48}$ A further technique which is frequently used is golden shares, or special decision-making or veto rights granted to certain shareholders, usually the state. ${ }^{49}$ Yet another mechanism used to curb the power of the acquirer to govern are various limitations on modifying the board structure. Thresholds for director removal can be increased to make board changes more difficult. ${ }^{50}$ Staggered boards could delay the acquirer's ability to change the board of directors after control acquisition. ${ }^{51}$

A particularly powerful defense is a restriction on the free transferability of shares, such as allowing the target board the right to refuse ownership to a purchaser of shares. In $16 \%$ of the sample countries the law allows share transfers to be restricted. A company using such share transfer restrictions may only be successfully taken over if the bidder has registered sufficient votes both to amend the relevant provisions of the articles of incorporation and to replace the board of directors refusing registration. Share transfer restrictions and voting caps can be further entrenched by imposing special majority requirements for their removal from the company articles of incorporation. ${ }^{52}$

\subsubsection{Defensive ownership and control structures}

Shareholder agreements bind several owners to common decision-making, voting unanimously, and acting in concert, as well as limiting share trading without, for example, the consent of all other contractual parties. Multiple classes of shares enable the controlling shareholder to keep a majority of the votes with a lower level of capital commitment than the requisite 50\%. In Argentina, companies can introduce a divergence between ownership and control by issuing negotiable obligations, participation bonds, non-voting shares or multiple vote shares. Pyramid ownership structures function in a very similar way to deviations from one share one vote, by permitting an owner to control a company with a small amount of capital. $^{53}$ In South Africa, the pyramid ownership structures had led to such ownership concentration that the JSE Listings Requirements forbade the listing of pyramid companies and their subsidiaries. Cross-shareholdings also permit a corporation to be controlled with less than $50 \%$ of capital. Cross shareholdings are especially popular in East Asia, e.g. 
Japan. ${ }^{54}$ About a quarter of the sample countries do not use ownership structures that separate ownership from control.

The index component we form is defined as the average of:

- 1 if it is forbidden by law to issue shares during a tender offer or if it requires shareholder approval, 0 otherwise;

- 1 if it is forbidden by law to sell major assets during a tender offer or if it requires shareholder approval, 0 otherwise;

- 1 if it is forbidden by law to use voting caps, 0 otherwise;

a 1 if it is forbidden by law to restrict share transferability, 0 otherwise;

- 1 if it is forbidden by law to use golden shares, 0 otherwise;

- 1 if shareholder agreements are not frequently used, 0 otherwise;

- 1 if at least two of the following three mechanisms are not frequently used among listed companies: multiple classes of shares, pyramid ownership structures, cross-shareholding ownership structures, 0 otherwise;

\subsection{Coding the index - the special case of the US}

As an example of the coding of the takeover index, take the case of the US. The US is also noteworthy since its takeover rules and especially anti-takeover defenses are atypical as compared to an international selection of countries.

US takeover provisions are relegated to the states (some provisions are imposed by dint of the federal level securities law). There is no mandatory offer at any level of ownership (coded as 0 ). Ownership disclosure is at $5 \%$ of any class, where also intention to control or to take private is disclosed, so the range where this information is available is $100 \%$ $5 \%=95 \% .^{55}$ If the investor intends to vie for control or owns up to $20 \%$ of a class of equity securities, the price of all deals needs to be disclosed including off-exchange deals (coded as 1). ${ }^{56}$ Takeover rules apply to registered and unregistered securities (including securities issued by a private company), irrespective of whether the target company is a public company (coded as 1). Fair price provisions, mandating that an acquirer pay the same price to minority as the highest price he has paid for the shares in the recent past, are available by statute (in 27 states), or by charter $(40 \%$ of the Fortune 500 companies have such a provision in their charter) (coded as 0.5 due to the lack of universal application). ${ }^{57}$ There is no law to mandate the same price be extended to share classes with lower voting rights (coded as 0).

\begin{tabular}{ll}
\hline Mandatory offer range & 0 \\
Range where intention to control is known & 0.95 \\
Range where intention to take private is known & 0.95 \\
Off-exchange price disclosed & 1 \\
Rules apply to non-listed firms & 1 \\
Fair price for minority & 0.5 \\
Fair price for all classes & 0 \\
\hline
\end{tabular}

Disclosure mandated during tender offers in Mandatory offer disclosure index 1 the US is strict. A bidder must file a tender offer registration statement with the SEC and all stock exchanges, and deliver a copy to the target company and any other bidders, as well as to all target shareholders. The bidder is provided relatively easy access to the shareholder list of the target company (via the courts). 
The target management gives an opinion to shareholders within 10 days of publication. The bidder's disclosure must contain all material information related to the offer, including interest of the bidder in the target; the bidder identity and ownership; future plans regarding the target company; past contracts, transactions and agreements between acquirer and target; the estimated consequences to the bidder's shareholders; and the source and amount of funds involved. The latter three items of information, together with the requirement for target board opinion, lead us to code the US disclosure variable as 1 . The information should be available to target shareholders within 3 days of the announcement of the tender offer, at the bidder's expense. ${ }^{58}$

If an acquirer tenders publicly for the shares, Fair price for non-tendering investors he must offer the same terms to any wiling Appraisal rights after a merger 1 shareholders within 20 days of the end of Sell-out provisions the offer (coded as 1). ${ }^{59}$ All state laws provide appraisal rights to shareholders after a merger, giving them the option to dissent and sell their shares at a fair market price (coded as 1). Sell-out provisions mandate the provision of detailed information from the company addressing whether the filing persons believe the transaction is fair to unaffiliated security holders and why (coded as 1$).^{60}$

On anti-takeover provisions, the US Anti-takeover tactics 0.71 averages $71 \%$ out of 100 (the average is computed on $1,1,0,0,1,1,1$, as follows). Share issues and asset sales are not forbidden during a tender offer, but do require shareholder approval (each coded as 1), voting caps and golden shares are allowed (each coded as 0), shares are freely transferable (coded as 1), shareholders agreements are not frequently used among listed companies (coded as 1), listed companies are mostly one-vote-one-share, and pyramids and cross-shareholdings are not frequent (coded as 1). The anti-takeover variable is particularly deficient at capturing the true extent of anti-takeover provision popularity in the US, since the tactics used in the country are fairly less typical (such as poison pills, which are endorsed in 25 US states, and staggered boards, both a virtually unknown phenomenon in emerging markets) across the sample of less developed capital markets. ${ }^{61}$ In the majority of the countries around the world, however, anti-takeover tactics are still as simple as maintaining concentrated ownership or using voting caps and transferability restrictions. Keeping in mind the bias (which leads us to exclude the US from regressions as a robustness check), we nevertheless have chosen this methodology since the alternative would understate the extent of anti-takeover defenses in a significant part of the sample countries.

The overall takeovers index is obtained by a simple average of the above 12 characteristics, rendering a value of 0.76 .

\section{Data and Empirical results}

The takeover laws questionnaire (see Appendix D) was constructed in cooperation with experts in takeover issues in nine pilot countries, Bulgaria, Chile, France, Germany, Japan, 
Lithuania, Nigeria, Switzerland, and the USA. The pilot countries were chosen to represent a diverse regional and income-level mix, in order to capture a wide range of potential takeover issues. Based on the pilot questionnaire, the concepts and information involving rules on minority protection and regulations affecting the frequency, ease and cost of control changes, were isolated. The legal provisions were grouped in 12 clusters of variables (see the definition of all variables in Table 2). Data for each selected legal provision was then collected for 50 countries (the list of countries together with essential market characteristics is listed in Table 3, and legal data sources are presented in Appendix E). The methodology covers the possible approaches for both friendly and hostile takeovers of a company.

The 12 index components characterizing takeover laws around the world are presented in Table 4. The takeover laws index is a simple average of these 12 characteristics (last column of Table 3). As collected, the data can answer such questions as "Do securities laws matter for development?", "Which regulations are "good" for investors, or for private sector growth?", and "Are different rules substitutable in their ability to achieve particular policy goals?". The exploration of the effect of specific takeover regulations on corporate value and markets is relegated to further research; this section limits itself to illustrating the overall importance of takeover laws to capital market breath and depth, over and above the effect of the general quality of the legal environment, and the prevailing level of investor protection.

Panel A of Table 5 shows the correlations among the 12 components of the takeover laws index. Overall, takeover rules seem highly correlated, indicating that national takeover laws that provide stricter investor protection would do so across the board on all takeover rules. An exception from this tendency concerns the choice of national legislations on extending takeover provisions to non-listed firms, which is not as strongly correlated to the strictness of overall takeover provisions. This pattern underlies the typical national legal structural separation between a capital markets law and a corporations law. Reformers of the former may not necessarily amend the latter law, thus limiting legal protections to capital markets investors, to the exclusion of private company shareholders, with a resulting lack of correlation of indicators. The same is true for appraisal rights and sell-out provisions, which are also typically legislated in the corporations law, not in capital markets regulations.

Note that some rules can exhibit a low correlation due to their high degree of substitutability. For example the correlation between appraisal rights after a merger and sell-out provisions is $17 \%$. Typically, appraisal rights are provided to minority shareholders in general, not specifically after a merger, and serve to permit the shareholder to sell his/her shares back to the corporation in case of dissent. This includes the right to sell shares to the corporation following a decision to go private. The purpose of sell-out provisions is largely the same, and for the specific case of going private, these two rights are substitutes. The choice of the legislator to adopt one or the other is largely a function of whether the country uses a common law approach (where appraisal rights are a standard feature), or a civil law framework.

Figures 1-3 provide an initial glimpse into the variation of takeover law quality across countries. Richer countries are associated with more elaborate pro-minority rules during changes in control. Countries with more listed companies and bigger capital markets are also 
those with stricter investor protection during takeovers. Finally, tougher takeover laws do decrease control values, but do not appear to dampen takeover activity.

Panel B of Table 5 confirms these initial impressions. It shows correlations of the takeover law index with various indicators of market development, efficacy of takeover activity, and general quality of the legal environment. The takeover law index is associated with capital market breath and depth, particularly with a high market valuation and active trading, and less strongly with the number of listed firms on the market. This is not a statistical test of causality or a measure of comparable effect of takeover law on various market characteristics; however, it seems to suggest the plausible hypothesis that takeover laws improve the overall corporate value and attractiveness of listed shares, and that effect comes from making each company more valuable, not just increasing the number of listed companies. Further testing can determine the validity of such a hypothesis. Another interesting hypothesis concerns the effect of stricter takeover regulations on the companies' decision to list.

This study confirms the negative relation between the takeover premium and the quality of takeover laws. The takeover law index is negatively correlated with measures of the value of corporate control or takeover premium, such as those of Dyck and Zingales (2004), Nenova (2003), and Rossi and Volpin (2004). ${ }^{62}$ The strong correlation shows that the value of control to the dominant owner (not to dispersed investors) is lower where takeover laws are stricter in their protection of minority investors. This conclusion is reassuring in demonstrating that minority takeover protections are indeed effective in national legislations. ${ }^{63}$

The takeover index is significantly and positively correlated with the level of takeover activity, as measured by the volume of takeovers, as well as the share of hostile deals (Rossi and Volpin 2004). Finally, takeover law as captured by the index is highly positively correlated with both rule of law $(66 \%)$ and investor protection as measured by La Porta et al (1998) (52\%).

Table 6 tests the effect of takeover regulations on market development in a regression framework. The table presents regressions of capital markets depth and breath measures on the takeovers law index controlling for general level of development, with or without controlling for the overall quality of the legal system and for general investor protection quality. The regressions in columns 1 and 4 of the upper panel and column 1 of the lower panels demonstrate a significant positive effect of takeover laws on the number of listed companies, market capitalization, and value traded on the stock exchange. Regressions using equity markets turnover (not presented) deliver similar results. The table also shows that good takeover laws positively impact the volume of control change deals, as well as the incidence of hostile deals and cross-border transactions (columns 4-6 of the lower panel). To illustrate the economic meaning of the regressions, column 4 of the upper panel shows that an introduction of one of the 12 takeover rules (mandating disclosure of prices on offexchange trades, or regulating appraisal rights after a merger, for example) will change that component value from 0 to 1 and increase the index by $1 / 12^{\text {th }}$, or 0.083 , thus contributing to an increase in stock market capitalization of $13 \%$ of GDP. In the case of Mexico, this means a jump in stock market value by $50 \%$ ! 
We control for the general quality of the legal framework using the variable "Rule of Law" from the International Country Risk Guide (columns 2 and 5 of the upper panel and column 2 of the lower panel). Takeover laws may not have a specific causal effect on stock markets on their own, but only proxy for the overall level of legal development in the country. Countries with well-functioning courts and a high general level of law and order will perforce have better developed markets. Failing to control for the general rule of law will permit the entire effect of good laws to be attributed to takeover laws alone, overstating their significance. Using alternative measures of the quality of laws renders similar results. Controlling for the overall quality of laws actually increases the effect of takeover provisions on capital market development, while leaving the significance of the takeover law coefficients undisturbed.

Columns 3 and 6 of the upper panel and 3 of the lower panel explore further the question of which specific laws matter. For that purpose, the regressions introduce the La Porta et al (1998) variable, anti-director rights, which measures the extent of overall minority investor protection in a country, across 49 countries around the world. ${ }^{64}$ The close relationship between some of the components of the anti-director rights and the takeover law indices creates collinearity problems which biases the coefficients and impairs their interpretation. More complex analyses are needed to carefully avoid this problem (such as ridge regression), which falls beyond the scope of this paper. Here, we will limit ourselves to noting that investor protection has a positive and largely significant effect on market development. When the general investor protection measure is included, the takeover index remains significant.

All regressions control for the level of country development, since it is a well-established fact that more developed countries boast more active and well-functioning capital markets. Including the level of country development in the regression avoids attributing to takeover laws the beneficial effect of high national income on capital markets. The control variable is the natural logarithm of income per capita (Atlas method). The regressions show that it has a positive and significant effect on market development (PPP income measures deliver identical results). These and all further tests have been repeated without the US, as well as with the variation of measuring the mandatory offer component of the takeover index as an indicator dummy. The results are not materially affected by those alternative specifications.

In sum, Table 6 shows that takeover laws have a considerable and economically important effect on market development, and are beneficial for minority investors by helping them share some of the value released during acquisitions. This effect is robust to the general level of national economic development, as well as the overall quality of the legal system. Moreover, the effect is specific to takeover laws, and cannot be attributed to the investor protection provided in other legislations relevant to corporations and capital markets.

Table 7 relates takeover laws to measures of the value of corporate control and the takeover premium. Stricter takeover laws are found to have a significant negative effect on the private benefits of the controlling corporate owner (columns 1-4), showing that indeed takeover laws do help share some of the corporate value with minority shareholders. This is especially important in emerging markets, where other mechanisms of transmitting value to minority 
investors may be limited (e.g. limited payment of dividends or inhibited capital gains due to liquidity constraints). Controlling for the overall quality of the legal framework and for the level of country development leaves the significance of this relationship unaltered.

Column 5 relates the takeover law index to the Rossi and Volpin (2004) takeover premium measure. The negative relationship found for the other measures of control value is maintained in the case of the R-V04 takeover premium, but lacks significance. As a caution, the R-V04 measure, as constructed, is interpreted to capture takeover gains for all shareholders, not only for the controlling owner. Since takeover laws have been coded in this study with an eye to minority protection, they would be expected to correlate positively with minority gains and negatively with control owner gains. The direction of the relationship with total gains is thus not clearly defined. Rossi and Volpin (2004) do find a negative relationship between their takeover premium measure and a variable proxying takeover law (specifically, an indicator variable for the presence of a mandatory offer rule).

Rossi and Volpin (2004) also find that takeovers tend to be paid for entirely by cash in countries with lower investor protection. This is supported by Table 7 as well, where we see a negative relationship between stricter takeover laws and the chance of a cash-financed offer (column 6). The coefficient is marginally insignificant. R-V04 interpret this finding as indicating that stocks are less popular as means of payment in countries with lower investor protection because stocks entail a higher risk of expropriation.

Table 8 illustrates an alternative use of the takeover laws variable, in answering policy questions on binding constraints for control market functioning. Control changes have been frequently noted to suffer from rigid labor laws, especially costly employee dismissals. This would especially hold if takeover gains are expected from restructuring a poorly governed or inefficiently-run company. Relating takeover volume and other indicators of control change activity to labor market laws as well as takeover laws shows that the preeminence of the latter as a determining factor.

\section{Conclusion}

Although acquisitions may differ across countries in their frequency and nature, corporate control transactions occur in all markets, in the natural growth cycle of a company, or for reasons of improving company value and benefiting from synergies between the acquirer and target. Takeover laws have been instituted to ensure an orderly process of changes in control, their transparent conduct, and equal opportunities for all investors, and in so doing, laws redistribute corporate value between the parties vying for control and the minority investors. The value involved is in practice considerable. The paper overviews takeover regulations in 50 developed and emerging markets around the world. The study uncovers the tradeoffs in selecting an appropriate set of takeover laws and regulations, determining the frequency and ease (cost) of acquisitions, their corporate governance (sentinel) functions, and the division of gains among controlling owners and minority investors. 
Even a simplistic view of regulations in a specific area, such as takeovers, presents an entangled body of law which is difficult to quantify. This paper presents a methodology for quantifying the takeover laws in a functional and detailed manner that permits analyses of the impact of the law on market development, as well as the exploration of the interplay among its component rules and their effect on corporations and markets. The study is also the first to analyze takeover laws cross-country, complementing the existing literature of single-country studies. This work relates the takeover law measure to existing cross-country measures of takeover market outcomes. As an illustration of the possible applications of the new legal index, some simple regressions are presented. Clearly more analysis is needed in this respect.

Takeover laws affect the depth and breath of capital markets and direct corporate value to investors. This effect is robust to the general level of national economic development, and the overall quality of the legal system, and is specific to takeover laws (as opposed to the general level of investor protection). The subject of securities regulation is vast, and further research is needed to explore the linkages among stock market regulations, investor protection, and market development. 


\section{Bibliography}

Andrade, Gregor, Mark Mitchell and Erik Stafford, 2001, "New Evidence and Perspectives on Mergers," Journal of Economic Perspectives 15 (2), 103-120.

Barca, Fabrizio (1995), On Corporate Governance in Italy: Issues, Facts and Agenda, Bank of Italy - Research Department Working Paper, September 1995.

Bebchuk, Lucian A. (1994), "Efficient and Inefficient Sales of Corporate Control," Quarterly Journal of Economics, Vol. 109, 957-993.

Bebchuk, Lucian A., and Allen Ferrell (2001), “A New Approach to Takeover Law and Regulatory Competition," Virginia Law Review, Vol. 87, 113-164.

Bebchuk, Lucian Arye, John C. Coates IV and Guhan Subramanian. The Powerful Antitakeover Force of Staggered Boards: Theory, Evidence and Policy. National Bureau of Economic Research, June 2002.

Becht, Marco, Patrick Bolton and Ailsa Röell, 2003, "Corporate Governance and Control," in George M. Constantinides, Milton Harris and René M. Stulz (eds.) Handbook of the Economics of Finance, Vol. 1a, Chapter 1, 1-109, Elsevier Science North-Holland, Amsterdam.

Begg, Peter F. C., "Corporate acquisitions and mergers: a practical guide to the legal, financial, and administrative implications", 1991.

Beny, Laura N., "Do Insider Trading Laws Matter? Some Preliminary Comparative Evidence", American Law and Economics Review, Vol. 7, No. 1, pp. 144-83, 2005.

Berglöf Erik, Bengt Holmström, Peter Högfeldt, Eva Meyersson Milgrom and Hans Tson Söderström, 2003, "Corporate Governance and Structural Change Challenges to European Corporate Ownership and Control," SNS Economic Policy Group Report.

Bergstrom, C., Rydqvist, K., 1990. Ownership of equity in dual-class firms. Journal of Banking and Finance 14, 255-269.

Bergstrom, C., Rydqvist, K., 1992. Differentiated bids for voting and restricted voting shares in public tender offers. Journal of Banking and Finance 16, 97-114.

Bertrand, Marianne, and Sendhil Mullainathan, "Corporate Governance and Executive Pay: Evidence from Takeover Legislation”, 1999.

Bethel, Jennifer E. and Gillan, Stuart L., "Corporate Voting and the Proxy Process: Managerial Control Versus Shareholder Oversight" (June 2000). Presented at Tuck-JFE Contemporary Corporate Governance Conference.

Bhagat, Sanjai and Black, Bernard S., "The Uncertain Relationship Between Board Composition and Firm Performance" Business Lawyer, Vol. 54, pp. 921-963, 1999.

Bhagat, Sanjai, Andrei Shleifer and Robert W. Vishny, 1990, "Hostile Takeovers in the 1980s: The Return to Corporate Specialization," Brooking Papers on Economic Activity. Microeconomics, Vol. 1990, 1-72.

Booth, Richard (2001), "Minority Discounts and Control Premiums in Appraisal Proceedings", University of Michigan School of Law Working paper.

Botero, J., S. Djankov, R. La Porta, F. Lopez-de-Silanes, and A. Shleifer, "Regulation of Labor", Quarterly Journal of Economics, November, 2004.

Bowne Securities Connect. Recent Developments in Merger \& Acquisition Regulation in Canada. March 2002. 
Bubnova, Nina B. (2000) "Governance Impact on Private Investment: Evidence from the International Patterns of Infrastructure Bond Risk Pricing” World Bank Technical Paper 488.

Burkart, Mike C., "Economics of Takeover Regulation". SITE Working Paper No. 99/06, Stockholm School of Economics.

Burkart, Mike C., Denis Gromb, and Fausto Panunzi, (1998), " Why Higher Takeover Premia Protect Minority Shareholders, Journal of Political Economy, Vol. 106 No. 1, February 1998.

Burkart, Mike C. and Panunzi, Fausto, "Agency Conflicts, Ownership Concentration, and Legal Shareholder Protection" (February 2001). CEPR Discussion Paper No. 2708.

Burkart, Mike and Fausto Panunzi, 2004, "Mandatory Bids, Squeeze-Out, Sell-Outs and the Dynamics of the Tender Offer Process," in: Guido Ferrarini, Klaus J. Hopt, Jaap Winter and Eddy Wymeersch (eds.), Modern Company and Takeover Law in Europe, p. 737-765, Oxford University Press, Oxford.

Burkart, Mike C. and Panunzi, Fausto, "Takeovers" (January 2006). ECGI - Finance Working Paper No. 118/2006.

Bushman, Robert M. and Smith, Abbie J. "Financial Accounting Information and Corporate Governance." Journal of Accounting and Economics, 2001, 32(1-3), pp. 237-333.

Carlin, Wendy and Mayer, Colin, "Finance, Investment and Growth" (June 25, 2000). Presented at Tuck-JFE Contemporary Corporate Governance Conference.

Charkham, J. 1994. Keeping good company: a study of corporate governance in five countries. Oxford: Oxford University Press.

Chen, Kevin C.W., Chen, Zhihong and Wei, K.C. John John, "Disclosure, Corporate Governance, and the Cost of Equity Capital: Evidence from Asia's Emerging Markets" (June 2003).

Claessens, C., Djankov, S., Lang, L., 2000. The separation of ownership and control in East Asian corporations. Journal of Financial Economics 58, 81-112.

Comment, R. and G.W. Schwert (1995) "Placebo or Poison Pill? Evidence on the deterrence and wealth effects of modern antitakeover measures", Journal of Financial Economics, 39 , pp. $3-43$.

Danielson, Morris and Jonathan Karpoff, "On the Uses of Corporate Governance Provisions", 1998.

Demirguc-Kunt, A., and V. Maksimovic, "Law, Finance, and Firm Growth", Journal of Finance, 1998, 2107-2137.

Diamond, Douglas W, 1984. "Financial Intermediation and Delegated Monitoring," Review of Economic Studies, Blackwell Publishing, vol. 51(3), pages 393-414.

Djankov, S., R. La Porta, F. Lopez-de-Silanes, and A. Shleifer, "Regulation of Entry", Quarterly Journal of Economics, February, 2002.

Djankov, S., R. La Porta, F. Lopez-de-Silanes, and A. Shleifer, "Courts", Quarterly Journal of Economics, May, 2003.

Djankov, S., C. McLiesh, and A. Shleifer, "Djankov, S., R. La Porta, F. Lopez-de-Silanes, and A. Shleifer, "Courts", unpublished manuscript, November, 2005.

Djankov, S., R. La Porta, F. Lopez-de-Silanes, and A. Shleifer, "The Law and Economics of SelfDealing", Quarterly Journal of Economics, unpublished manuscript, December, 2005.

Dodd, P., Warner, J., 1983. On corporate governance: a study of proxy contests. Journal of 
Financial Economics 11, 401-439.

Dyck, Alexander and Zingales, Luigi. "Private Benefits of Control: An International Comparison." Journal of Finance, 2004, 59(2), pp. 537-600.

Easterbrook, Frank H. and Fischel, Daniel R. (1983), 'Voting in Corporate Law', 26 Journal of Law and Economics, 395-427.

Escobar, Ricardo, Carey Cía. Ltda., "Report on Corporate Governance Issues in Chile", 2000.

Fernandez, Jose W., Antonio Delpino, Jose Lau Dan and Rafael Diaz-Granados, Corporate Caveat Emptor: Minority Shareholder Rights in Mexico, Chile, Brazil, Venezuela and Argentina, Inter-American Law Review, Vol. 32: 2001.

Francis, Jere R., Khurana, Inder K. and Pereira, Raynolde, "Investor Protection Laws, Accounting and Auditing Around the World" (October 2001).

Franks J R,Mayer C, "Ownership and control in Germany", Review of Financial Studies 2001 Vol 14 p 943-977.

Franks J R, Mayer C, "Hostile Takeovers and the Correction of Managerial failure", Journal of Financial Economics 1996 Vol 40:1 p 163-181.

Frost, Carol A, Gordon, Elizabeth A. and Hayes, Andrew F., "Stock Exchange Disclosure and Market Liquidity: An Analysis of 50 International Exchanges" (October 14, 2002).

Gilson, Stuart (1990). "Bankruptcy, Boards, Banks, and Blockholders," Journal of Financial Economics, 27, 315-355.

Global Competition Review, "Corporate Governance in 23 jurisdictions worldwide", 2002.

Global Competition Review: "Mergers and Acquisitions in 29 jurisdictions worldwide", 2002.

Goergen, Marc and Renneboog, Luc D.R., "Shareholder Wealth Effects of European Domestic and Cross-Border Takeover Bids" (January 2003). ECGI - Finance Working Paper No. 08/2003.

Goergen, Marc, Marina Martynova, and Luc Renneboog, "Corporate Governance Convergence: Evidence from takeover regulation" (April 2005). ECGI - Law Working Paper No. 33/2005.

Gomes, Armando, “Going Public without Governance: Managerial Reputation Effects”, Journal of Finance, Vol. 55, No. 2, April 2000.

Gompers, Paul, Joy Ishii, and Andrew Metrick, "Corporate Governance and Equity Prices", Quarterly Journal of Economics, Vol. 118 (1), pp. 107-155, February 2003.

Gordon, L. A., and J. Pound, 1993, "Information, Ownership Structure, and Shareholder Voting: Evidence from Shareholder-Sponsored Corporate Governance Proposals," The Journal of Finance, 48, 697-718.

Gorton, Gary \& Schmid, Frank A., 2000. "Universal banking and the performance of German firms," Journal of Financial Economics, Elsevier, vol. 58(1-2), pages 29-80.

Grossman, Sanford J., and Oliver D. Hart, 1980. "Takeover Bids, the Free-Rider Problem, and the Theory of the Corporation," Bell Journal of Economics, The RAND Corporation, vol. 11(1), pages 42-64.

Hacimahmutoglu, S., Barriers to Corporate Takeovers in Turkish Law (1998).

Hall, Brian J., and Jeffrey B. Liebman, 1998. "Are CEOs Really Paid Like Bureaucrats?, he Quarterly Journal of Economics, MIT Press, vol. 113(3), pages 653-691.

Himmelberg, Charles, Glenn Hubbard, and Inessa Love, "Investor Protection, Ownership, and Investment", Working Paper, Columbia University, June 2000.

Holderness, Clifford G. and Dennis P. Sheehan, 1988. "The Role of Major Shareholders in Publicly Held Corporations." Journal of Financial Economics 20: 317-46.

Horner, M., 1988. The value of the corporate voting right: evidence from Switzerland. Journal of Banking and Finance 12, 69-83. 
International Society of Securities Administrators, 2002. ISSA Handbook. Zurich, Switzerland. Jensen, Michael C., 1986, Agency costs of free cash f lows, corporate finance, and takeovers, American Economic Review 76, 323-329.

Jensen, Michael C., 1988, "Takeovers: Their Causes and Consequences," Journal of Economic Perspectives, 2(1): 21-48.

Jensen, Michael C \& Murphy, Kevin J, 1990. "Performance Pay and Top-Management Incentives," Journal of Political Economy, University of Chicago Press, vol. 98(2), pages 22564.

Jensen, Michael C., and Richard S. Ruback, 1983, The market for corporate control: The scientific evidence, Journal of Financial Economics 11, 5-50.

Kang, Jun-koo, and Anil Shivdasani, 1995, Firm performance, corporate governance, and top executive turnover in Japan, Journal of Financial Economics 38, 29-58.

Kaplan, Steven N., 1994, Top executive rewards and firm performance: A comparison of Japan and the United States, Journal of Political Economy 102, 510-546.

Kaplan, Steven, and Bernadette Minton, 1994, "Appointments of outsiders to Japanese boards: determinants and implications for manager," Journal of Financial Economics 36, 225-257.

Martin, Kenneth J and McConnell, John J, 1991. "Corporate Performance, Corporate Takeovers, and Management Turnover," Journal of Finance, vol. 46(2), pages 671-87.

La Porta, R., Lopez-de-Silanes, F., Shleifer, A., "Corporate Ownership Around the World", Journal of Finance, April, 1999.

La Porta, R., Lopez-de-Silanes, F., Shleifer, A., Pop-Eleches, C., 2004. Judicial Checks and Balances. Journal of Political Economy.

La Porta, R., Lopez-de-Silanes, F., Shleifer, A., Vishny, R., 1997. Legal determinants of external finance. Journal of Finance 52, 1131-1150.

La Porta, R., Lopez-de-Silanes, F., Shleifer, A., Vishny, R., 1998. Law and finance. Journal of Political Economy 106, 1113-1155.

La Porta, R., Lopez-de-Silanes, F., Shleifer, A., Vishny, R., 2000a. Agency problems and dividend policies around the world. Journal of Finance 55, 1-33.

La Porta, R., Lopez-de-Silanes, F., Shleifer, A., Vishny, R., 2000b. Investor protection and corporate governance. Journal of Financial Economics 58, 3-27.

La Porta, R., Lopez-de-Silanes, F., Shleifer, A., Vishny, R., 2002. Investor protection and corporate valuation. Journal of Finance, 57(3).

La Porta, R., Lopez-de-Silanes, F., Shleifer, A., 2006. What Works in Securities Laws? Journal of Finance, forthcoming.

Lease, R., McConnell, J., Mikkelson, W., 1983. The market value of control on publicly traded corporations. Journal of Financial Economics 11, 439-471.

Levine, Ross (1997). Financial development and economic growth: views and agenda. Journal of Economic Literature, 35, 688-726.

Licht, A.N., Goldschmidt, C. and Schwartz, S.H. (2003) 'Culture, Law and Corporate Governance', Radzyner School of Law Working Paper, Interdisciplinary Center: Herzliya.

Lombardo, Davide \& Pagano, Marco, 1999. "Legal Determinants of the Return on Equity," CEPR Discussion Papers 2275, C.E.P.R. Discussion Papers.

Megginson, W., 1990. Restricted voting stock, acquisition premiums, and the market value of corporate control. The Financial Review 25, 175-198.

Modigliani, F., Perotti, E., 1997. Protection of minority interest and the development of security markets. Managerial and Decision Economics 18, 519-528. 
Morck, Randal, “Corporate Governance and Family Control”, GCGF Discussion paper 1, fig. 2.

Morck, Randall, Andrei Shleifer, and Robert W. Vishny, 1990, Do managerial objectives drive bad acquisitions, Journal of Finance 45, 31-48.

Morck, Randall, Andrei Shleifer, and Robert W. Vishny, 1990, Alternative Mechanisms for Corporate Control, American Economic Review, September, 1989.

Nenova, T., 2001. Essays on Corporate Control. Ph.D. Thesis. Harvard University, Cambridge, MA.

Nenova, T., 2003. The value of corporate voting rights and control: A cross-country analysis. Journal of Financial Economics, 68 (3), pp. 325-351.

"A Corporate Governance Agenda for Developing Countries", Contaduría y Administración, Universidad Nacional Autónoma de México, N 217, 2005.

"Corporate Law and Control Values in Brazil", Latin American Business Review, Federal University of Rio de Janiero, Volume 6(3), p. 1-37, 2005.

Pagano, M. (1993). Financial markets and growth: an overview. European Economic Review, 37, 613-622.

Palepu, K.G., 1986. Predicting takeover targets: A methodological and empirical analysis. Journal of Accounting and Economics 8, 3-35.

Pistor, Katharina, Martin Raiser, Syanislav Gelfer "Law and Finance in Transition Economies" EBRD Working Paper 48 (2000).

Rajan, R. and Zingales, L. (1998) 'Financial Dependence and Growth', American Economic Review 88: 559-587.

Roll, Richard. 1986. "The Hubris Hypothesis of Corporate Takeovers," Journal of Business, University of Chicago Press, vol. 59(2), pages 197-216.

Rossi, Stefano and Volpin, Paolo F., (2004) "Cross-Country Determinants of Mergers and Acquisitions", Journal of Financial Economics 74, pp. 277-304.

Rydqvist, K., 1993. Dual-class shares: a review. Oxford Review of Economic Policy 8 , 45-57.

Scharfstein, David, "The Disciplinary Role of Takeovers," Review of Economic Studies, April 1988, pp. 185-200.

Shleifer, A., Summers, L., 1988 "Breach of Trust in Hostile Takeovers", in Alan J. Auerbach, editor, Corporate Takeovers: Causes and Consequences. Chicago: University of Chicago Press, 1988.

Shleifer, A., Vishny, R., 1986 "Large Shareholders and Corporate Control", Journal of Political Economy, June, 1986.

Shleifer, A., Vishny, R., 1988 "Value Maximization and the Acquisition Process", Journal of Economic Perspectives, Winter, 1988.

Shleifer, A., Vishny, R., 1991 "Takeovers in the '60s and the '80s: Evidence and Implications", Strategic Management Journal, December, 1991.

Shleifer, A., Vishny, R., 2003 "Stock Market Driven Acquisitions", Journal of Financial Economics, December, 2003.

Smith, CW, and JB Warner. 1979. "On Financial Contracting: An Analysis of Bond Covenants," Journal of Financial Economics 7, 117-61.

Subramanian, Guhan, "Bargaining in the Shadow of Takeover Defenses". Yale Law Journal, Vol. 113, No. 3, December 2003.

Vogt, Nedim Peter, and Rolf Watter, Mergers \& Acquisitions in Switzerland, 1995. 
Walker, Eduardo, "Gobierno Corporativo, Protección a los Accionistas Minoritarios y Tomas de Control," Elementos Conceptuales de la Ley de OPAS, Serie Documentos de Discusión Nº1, SVS, 2001

Warner, JB, Watts, RL, \& Wruck, KH (1988) Stock prices and top management changes. Journal of Financial Economics, 20, 461-492.

Weisbach, M., 1988, Outside directors and CEO turnover, Journal of Financial Economics 20, 431-60.

Yurtoglu, B. Burcin, Corporate Governance and Implications for Minority Shareholders in Turkey, (2001 data).

Zingales, L., 1994. The value of the voting right: a study of the Milan stock exchange experience. The Review of Financial Studies 7, 125-148.

Zingales, L., 1995. What determines the value of corporate votes. The Quarterly Journal of Economics 110, 1047-1073.

Zingales, Luigi , "The Costs and Benefits of Financial Market Regulation" (April 2004). ECGI Law Working Paper No. 21/2004. 
Figure 2

Richer countries protect minorities more during takeovers

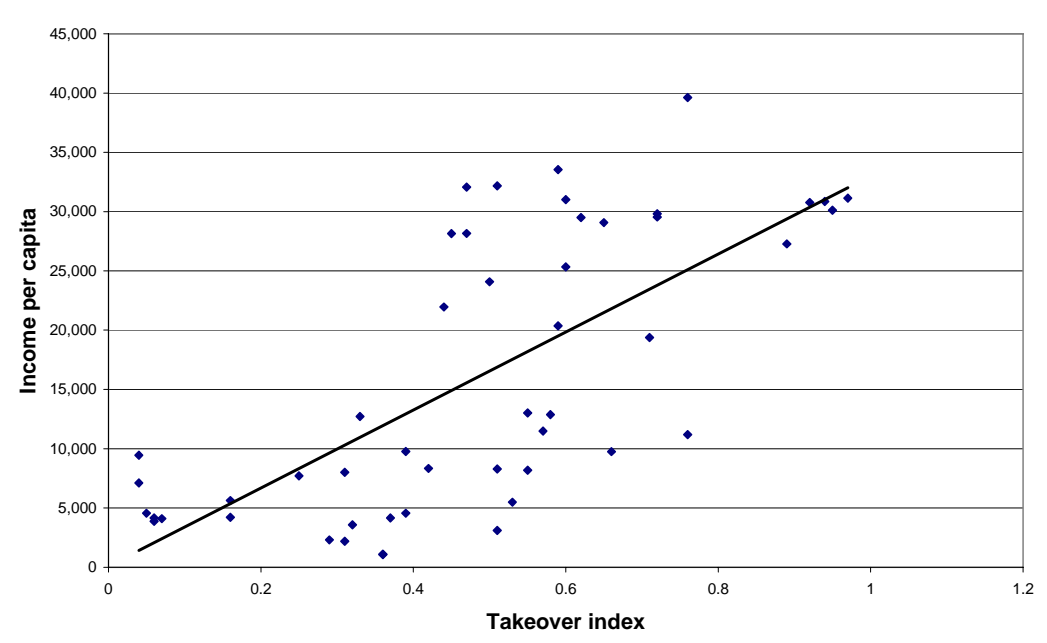

Figure 3

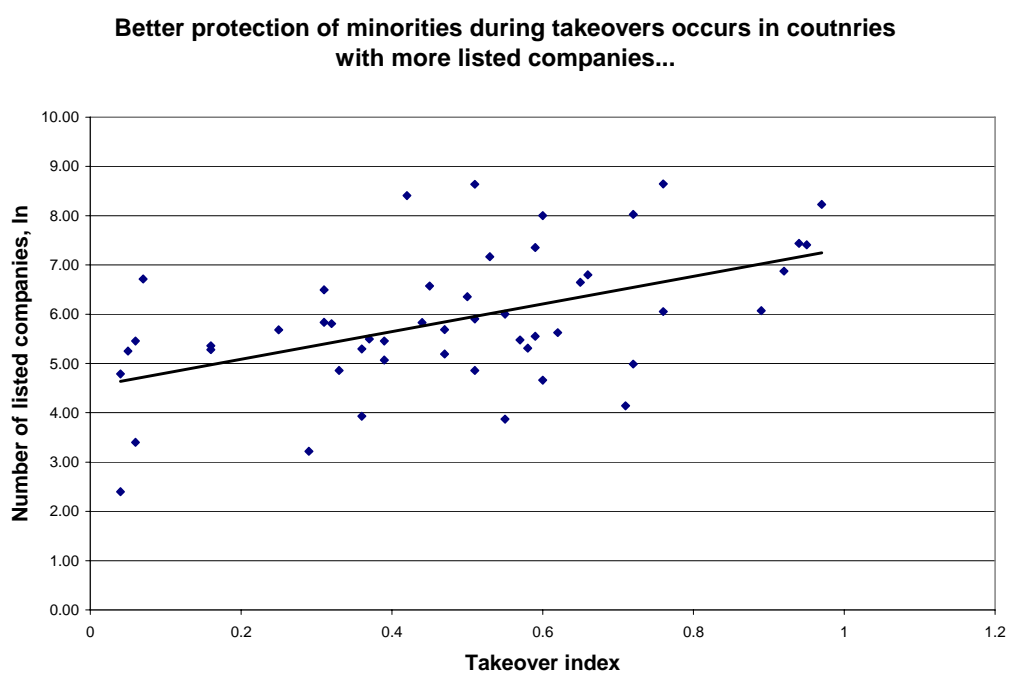

...and larger stock makrets

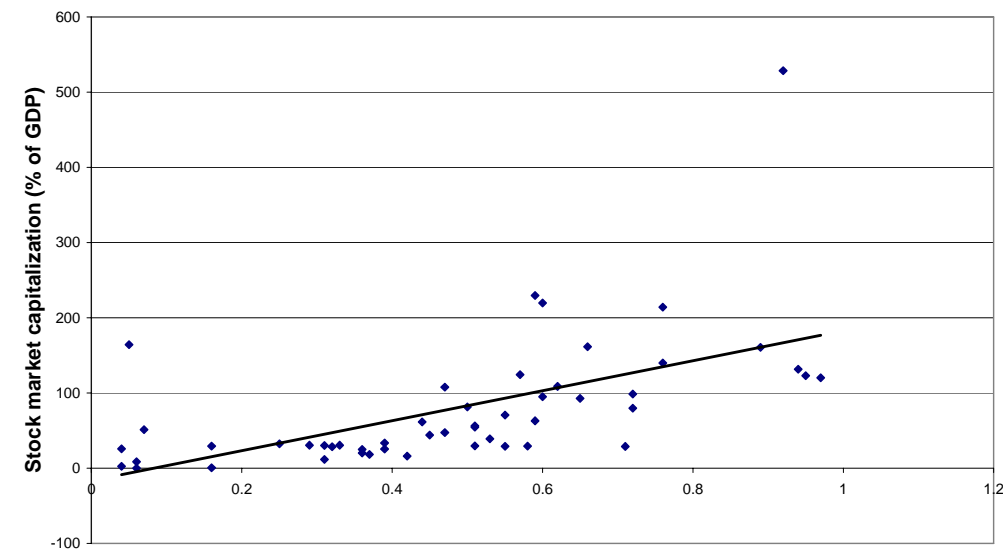

Takeover index 


\section{Figure 4}

Control is not as valuabvle in countries with better protection of minorities during takeovers...

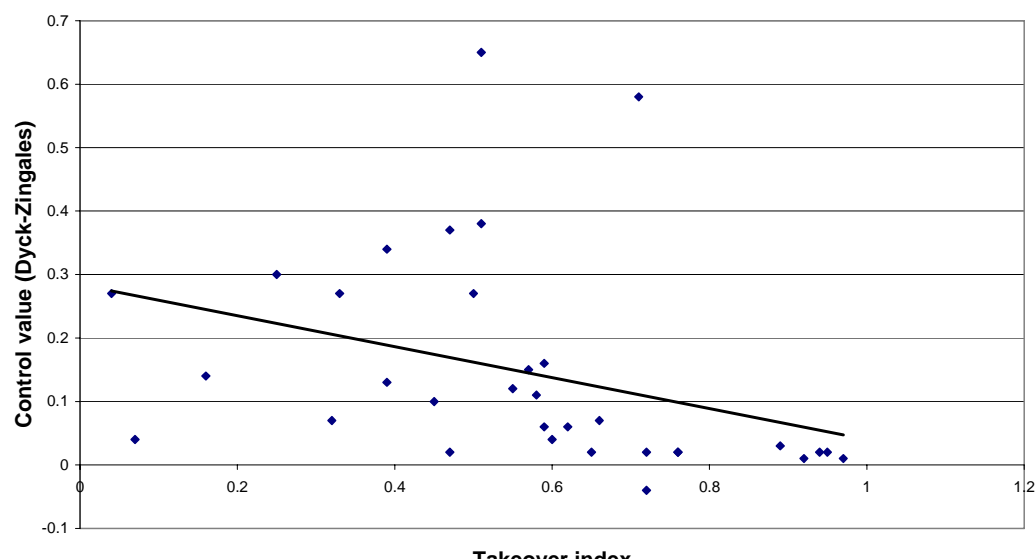

Takeover index

... but does not dampen the volume of takeover activity

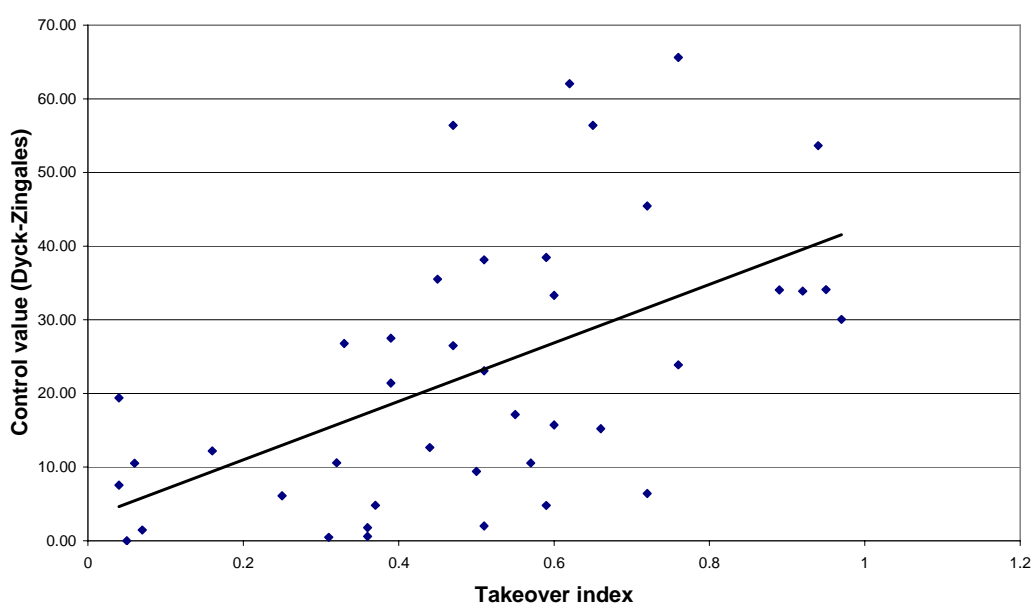




\section{Definitions of variables}

Table 2

\section{Variable}

Mandatory offer range

Range where intention to control is known

Range where intention to take private is known

Off-exchange price disclosed

Rules apply to non-listed firms

Fair price for minority

Fair price for all classes

Offer disclosure index

Fair price for non-tendering investors

Appraisal rights after a merger

Sell-out provisions

Anti-takeover tactics

\section{Definition}

The range where the owner can only acquire shares via a tender offer, e.g. if any owner above $30 \%$ must make a mandatory offer, the variable will take the value of $70 \%$. As another example, if any owner above $30 \%$ can only increase his/her stake by declaring a partial tender offer, the variable will take the value of $70 \%$.

The range where the owner must disclose his intentions to acquire control, e.g. if any owner above $15 \%$ must declare whether it is his/her intention to attempt to acquire control, the range is from $15 \%$ to $100 \%$, or 0.85 .

The range where the owner must disclose his intentions to take the company private, e.g. if any owner above $30 \%$ must declare whether it is his/her intention to take the company private, the range is from $30 \%$ to $100 \%$, or 0.70 .

The variable takes the value of 1 if the price at which off-market deals are concluded is publicly disclosed or if off-market purchases are banned, 0 otherwise.

1 if any public offer rules (rules for mandatory or partial offers, or taking private rules) apply to private firms, 0 otherwise.

1 if the mandatory offer is restricted by law to offer some measure of a market price (usually an average of the past several months of trading), 0 otherwise.

1 if the mandatory offer (or tender offer, in the absence of mandatory offer rules by law) must be for all classes (including non-voting classes) at a comparable ("fair") price by any legal definition that the country laws provide, or if by law companies are constrained to have only one class of shares listed; 0 otherwise.

The average of: (1) 1 for disclosure of past contracts, transactions and agreements between acquirer and target, 0 otherwise; (2) 1 for disclosure of the estimated consequences to bidder's shareholders (if a corporation), 0 otherwise; (3) 1 for disclosure of the target board opinion, 0 otherwise; (4) 1 for disclosure of the proof of sources to finance the offer, 0 otherwise. This refers to disclosure in the public offer prospectus of a mandatory offer (in the absence of mandatory offer rules, it refers to any tender offer rules; 0 if no such rules exist.

1 if shareholders that did not tender during the term of the offer have the right for a given period after the offer to be bought out at the same terms, 0 otherwise.

1 if withdrawal rights are available to shareholders who abstained or dissented from the merger at the annual shareholder meeting where the merger was approved, if withdrawal rights are available at a market price; 0.5 if the same withdrawal rights are available, but at book value (or the law does not specify the price), 0 if the law does not provide for withdrawal rights.

1 if minority shareholders can require the majority owner to buy them out at a certain level of ownership (usually $90 \%$ or more), and the law provides for some measure of a market ("fair") price for the sell-out; 0.5 if sell-out rights exist, but at any price (usually book value); 0 otherwise.

The average of: (1) 1 if it is forbidden by law to issue shares during a tender offer or if shareholder approval is needed, 0 otherwise; (2) 1 if it is forbidden by law to sell major assets during a tender offer or if shareholder approval is needed, 0 otherwise; (3) 1 if it is forbidden by law to use voting caps, 0 otherwise; (4) 1 if it is forbidden by law to restrict share transferability, 0 otherwise; (5) 1 if it is forbidden by law to use golden shares, 0 otherwise; (6) 1 if shareholder agreements are not frequently used, 0 otherwise; (7) 1 if at least two of the following three mechanisms are not frequently used among listed companies: multiple classes of shares, pyramid ownership structures, cross-shareholding ownership structures, 0 otherwise. 
Table 3

Basic economic indicators and the takeover law index

\begin{tabular}{|c|c|c|c|c|c|}
\hline Country & $\begin{array}{l}\text { Income per } \\
\text { capita } 2004 \\
\text { (USD\$) }\end{array}$ & $\begin{array}{l}\text { Number of listed } \\
\text { companies, } 2004\end{array}$ & $\begin{array}{l}\text { Market capitalization of } \\
\text { listed companies (\% of } \\
\text { GDP) } 2004\end{array}$ & $\begin{array}{l}\text { Stocks traded, } \\
\text { total value }(\% \text { of } \\
\text { GDP) } 2004\end{array}$ & $\begin{array}{l}\text { Takeover } \\
\text { index }\end{array}$ \\
\hline ARGENTINA & 12,723 & 129 & 30.65 & 5.04 & 0.33 \\
\hline ARMENIA & 4,222 & 213 & 0.51 & 0.05 & 0.16 \\
\hline AZERBAIJAN & 4,175 & 234 & & 0.02 & 0.06 \\
\hline AUSTRALIA & 30,116 & 1,649 & 122.99 & 81.46 & 0.95 \\
\hline AUSTRIA & 32,176 & 129 & 29.58 & 8.21 & 0.51 \\
\hline BELGIUM & 31,009 & 106 & 219.64 & 20.09 & 0.60 \\
\hline BRAZIL & 8,297 & 367 & 54.62 & 15.47 & 0.51 \\
\hline BULGARIA & 8,007 & 342 & 11.62 & 2.12 & 0.31 \\
\hline CANADA & 31,129 & 3,756 & 120.18 & 66.74 & 0.97 \\
\hline CHILE & 11,487 & 240 & 124.40 & 12.32 & 0.57 \\
\hline CHINA & 5,495 & 1,296 & 38.79 & 45.37 & 0.53 \\
\hline COLOMBIA & 7,121 & 120 & 25.90 & 1.50 & 0.04 \\
\hline CZECH R & 19,381 & 63 & 28.83 & 16.50 & 0.71 \\
\hline ECUADOR & 3,885 & 30 & 8.52 & 0.33 & 0.06 \\
\hline EGYPT & 4,103 & 824 & 51.25 & 7.46 & 0.07 \\
\hline FINLAND & 29,816 & 147 & 98.48 & 117.93 & 0.72 \\
\hline FRANCE & 29,077 & 772 & 92.74 & 65.50 & 0.65 \\
\hline GERMANY & 28,147 & 715 & 44.01 & 51.80 & 0.45 \\
\hline GHANA & 2,316 & 25 & 30.67 & 0.76 & 0.29 \\
\hline GREECE & 21,954 & 341 & 61.57 & 21.38 & 0.44 \\
\hline HONG KONG & 30,779 & 968 & 528.49 & 269.30 & 0.92 \\
\hline INDIA & 3,115 & 5,644 & 56.06 & 54.79 & 0.51 \\
\hline INDONESIA & 3,583 & 333 & 28.43 & 10.70 & 0.32 \\
\hline ISRAEL & 24,082 & 576 & 81.25 & 39.33 & 0.50 \\
\hline ITALY & 28,162 & 295 & 47.21 & 48.10 & 0.47 \\
\hline JAPAN & 29,539 & 3,058 & 79.56 & 74.20 & 0.72 \\
\hline JORDAN & 4,571 & 191 & 164.20 & 47.59 & 0.05 \\
\hline KENYA & 1,063 & 51 & 24.94 & 2.07 & 0.36 \\
\hline KOREA & 20,371 & 1,563 & 63.07 & 94.00 & 0.59 \\
\hline LITHUANIA & 13,021 & 48 & 29.03 & 2.08 & 0.55 \\
\hline MALAYSIA & 9,760 & 897 & 161.33 & 50.84 & 0.66 \\
\hline MEXICO & 9,774 & 159 & 25.42 & 6.33 & 0.39 \\
\hline NETHERLANDS & 32,056 & 180 & 107.80 & 104.67 & 0.47 \\
\hline NIGERIA & 1,113 & 200 & 20.06 & 2.31 & 0.36 \\
\hline PAKISTAN & 2,210 & 663 & 30.17 & 76.86 & 0.31 \\
\hline PERU & 5,641 & 197 & 29.41 & 1.65 & 0.16 \\
\hline PHILIPPINES & 4,558 & 234 & 33.49 & 4.24 & 0.39 \\
\hline POLAND & 12,881 & 203 & 29.40 & 6.85 & 0.58 \\
\hline ROMANIA & 8,342 & 4,484 & 16.11 & 1.29 & 0.42 \\
\hline SINGAPORE & 27,273 & 434 & 160.60 & 76.12 & 0.89 \\
\hline SOUTH AFRICA & 11,190 & 426 & 214.09 & 76.53 & 0.76 \\
\hline SPAIN & 25,341 & 2,986 & 94.88 & 120.50 & 0.60 \\
\hline SRI LANKA & 4,173 & 244 & 18.23 & 2.90 & 0.37 \\
\hline SWEDEN & 29,499 & 278 & 108.77 & 119.06 & 0.62 \\
\hline SWITZERLAND & 33,541 & 258 & 229.74 & 202.28 & 0.59 \\
\hline THAILAND & 8,179 & 405 & 70.58 & 66.74 & 0.55 \\
\hline TURKEY & 7,710 & 294 & 32.55 & 48.82 & 0.25 \\
\hline UK & 30,843 & 1,701 & 131.53 & 173.16 & 0.94 \\
\hline URUGUAY & 9,465 & 11 & 2.51 & 0.00 & 0.04 \\
\hline USA & 39,618 & 5,685 & 139.91 & 165.89 & 0.76 \\
\hline
\end{tabular}


Table 4.

\section{Components of the takeover law index}

\begin{tabular}{|c|c|c|c|c|c|c|c|c|c|c|c|c|}
\hline Country & $\begin{array}{l}\text { Mandatory } \\
\text { offer range }\end{array}$ & $\begin{array}{l}\text { Range where } \\
\text { intention to } \\
\text { control is } \\
\text { known }\end{array}$ & $\begin{array}{l}\text { Range where } \\
\text { intention to } \\
\text { take private } \\
\text { is known }\end{array}$ & $\begin{array}{l}\text { Off- } \\
\text { exchange } \\
\text { price } \\
\text { disclosed }\end{array}$ & $\begin{array}{l}\text { Rules } \\
\text { apply to } \\
\text { non-listed } \\
\text { firms }\end{array}$ & $\begin{array}{l}\text { Fair price } \\
\text { for } \\
\text { minority }\end{array}$ & $\begin{array}{l}\text { Fair price } \\
\text { for all } \\
\text { classes }\end{array}$ & $\begin{array}{l}\text { Offer } \\
\text { disclosure } \\
\text { index }\end{array}$ & $\begin{array}{l}\text { Fair price } \\
\text { for non- } \\
\text { tendering } \\
\text { investors }\end{array}$ & $\begin{array}{l}\text { Appraisal } \\
\text { rights after } \\
\text { a merger }\end{array}$ & $\begin{array}{l}\text { Sell-out } \\
\text { provisions }\end{array}$ & $\begin{array}{l}\text { Anti- } \\
\text { takeover } \\
\text { tactics }\end{array}$ \\
\hline Argentina & 0.49 & 0.50 & 0.25 & 0 & 0 & 1 & 0 & 0.25 & 0 & 0 & 1 & 0.43 \\
\hline Armenia & 0 & 0.50 & 0.25 & 0 & 0 & 0 & 0 & 0 & 0 & 1 & 0 & 0.14 \\
\hline Azerbaijan & 0 & 0.50 & 0 & 0 & 0 & 0 & 0 & 0 & 0 & 0 & 0 & 0.17 \\
\hline Australia & 0.80 & 0.80 & 0.80 & 1 & 1 & 1 & 1 & 1.00 & 1 & 1 & 1 & 1.00 \\
\hline Austria & 0.70 & 0.70 & 0.70 & n.a. & 0 & 1 & 1 & 0.50 & 1 & 0 & 0 & 0.00 \\
\hline Belgium & 0.50 & 0.80 & 0.80 & n.a. & 1 & 1 & 1 & 0.50 & 1 & 0 & 0 & 0.00 \\
\hline Brazil & 0.67 & 0.95 & 0.67 & 1 & 0 & 0 & 1 & 0.67 & 1 & 0 & 0 & 0.14 \\
\hline Bulgaria & 0.50 & 0.90 & 0.10 & 0 & 0 & 1 & 0 & 0.50 & 0 & n.a. & 0 & 0.43 \\
\hline Canada & 0.80 & 0.90 & 0.90 & 1 & 1 & 1 & 1 & 1.00 & 1 & 1 & 1 & 1.00 \\
\hline Chile & 0.50 & 0.50 & 0.50 & n.a. & 1 & 1 & 0 & 0.50 & 1 & 1 & 0 & 0.30 \\
\hline China & 0.70 & 0.70 & 0.25 & n.a. & 0 & 1 & 1 & 0 & 1 & 1 & 0 & 0.17 \\
\hline Colombia & 0 & 0.50 & 0 & 0 & 0 & 0 & 0 & 0 & 0 & 0 & 0 & 0.00 \\
\hline Czech R & 0.60 & 0.60 & 0.10 & n.a. & 1 & 1 & 1 & 0.25 & 1 & n.a. & 1 & 0.57 \\
\hline Ecuador & 0 & 0.50 & 0 & 0 & 0 & 0 & 0 & 0 & 0 & 0 & 0 & 0.17 \\
\hline Egypt & 0 & 0.50 & 0 & 0 & 0 & 0 & 0 & 0 & 0 & 0 & 0 & 0.29 \\
\hline Finland & 0.33 & 0.50 & 0.10 & n.a. & 1 & 1 & 1 & 0.50 & 1 & 1 & 1 & 0.50 \\
\hline France & 0.67 & 0.90 & 0.90 & 1 & 0 & 1 & 0 & 0.75 & 1 & 0 & 1 & 0.57 \\
\hline Germany & 0.70 & 0.70 & 0.70 & 1 & 0 & 1 & 0 & 0.75 & 0 & 0 & 0 & 0.57 \\
\hline Ghana & 0.75 & 0.75 & 0.25 & 0 & 0 & 1 & 0 & 0.25 & 0 & 0 & 0 & 0.43 \\
\hline Greece & 0.50 & 0.50 & 0.50 & n.a. & 0 & 1 & 1 & 0.75 & 0 & 0 & 0 & 0.57 \\
\hline Hong Kong & 0.70 & 0.90 & 0.70 & 1 & 1 & 1 & 1 & 1 & 1 & 1 & 1 & 0.71 \\
\hline India & 0.85 & 0.85 & 0.10 & n.a. & 0 & 1 & 0 & 0.25 & 1 & 1 & 0 & 0.57 \\
\hline Indonesia & 0.75 & 0.75 & 0.75 & n.a. & 0 & 1 & 0 & 0.25 & 0 & 0 & 0 & 0.00 \\
\hline Israel & 0.75 & 0.75 & 0.75 & n.a. & 0 & 1 & 0 & 0.67 & 1 & 0 & 0 & 0.57 \\
\hline
\end{tabular}




\begin{tabular}{|c|c|c|c|c|c|c|c|c|c|c|c|c|}
\hline Italy & 0.70 & 0.70 & 0.70 & n.a. & 1 & 1 & 0 & 0.67 & 0 & 0 & 0 & 0.43 \\
\hline Japan & 0.67 & 0.95 & 0.67 & 1 & 1 & 1 & 1 & 1.00 & 0 & 1 & 0 & 0.29 \\
\hline Jordan & 0 & 0.50 & 0 & 0 & 0 & 0 & 0 & 0 & 0 & 0 & 0 & 0.14 \\
\hline Kenya & 0.75 & 0.50 & 0.50 & 0 & 0 & 0 & 0 & 0.75 & 1 & 0 & 0 & 0.80 \\
\hline Korea & 0.95 & 0.95 & 0.95 & 1 & 0 & 0 & 1 & 0.50 & 0 & 1 & 0 & 0.71 \\
\hline Lithuania & 0.60 & 0.60 & 0.60 & 1 & 0 & 1 & 0 & 0.50 & 0 & n.a. & 1 & 0.71 \\
\hline Malaysia & 0.67 & 0.67 & 0.67 & n.a. & 1 & 1 & 1 & 0.50 & 0 & 0 & 1 & 0.71 \\
\hline Mexico & 0.50 & 0.50 & 0 & 0 & 0 & 1 & 1 & 0.50 & 0 & 0 & 1 & 0.20 \\
\hline Netherlands & 0.50 & 0.50 & 0.05 & n.a. & 1 & 0 & 1 & 1.00 & 1 & 0 & 0 & 0.17 \\
\hline Nigeria & 0.50 & 0.50 & 0.25 & n.a. & 0 & 0 & 0 & 0.25 & 1 & 0 & 1 & 0.43 \\
\hline Pakistan & 0.49 & 0.50 & 0.50 & n.a. & 0 & 0 & 1 & 0.25 & 0 & 0 & 0 & 0.71 \\
\hline Peru & 0 & 0.50 & 0.33 & 0 & 0 & 1 & 0 & 0 & 0 & 0 & 0 & 0.14 \\
\hline Philippines & 0.50 & 0.95 & 0.05 & n.a. & 0 & 1 & 0 & 0.50 & 0 & 1 & 0 & 0.29 \\
\hline Poland & 0.75 & 0.90 & 0.75 & 1 & 0 & 1 & 1 & 0.50 & 0 & n.a. & 0 & 0.50 \\
\hline Romania & 0.67 & 0.67 & 0.67 & n.a. & 0 & 1 & 0 & n.a. & 0 & 0 & 1 & 0.14 \\
\hline Singapore & 0.70 & 0.70 & 0.70 & 1 & 1 & 1 & 1 & 1.00 & 1 & 1 & 1 & 0.57 \\
\hline South Africa & 0.65 & 0.65 & 0.65 & n.a. & 1 & 1 & 1 & 0.75 & 1 & 0 & 1 & 0.71 \\
\hline Spain & 0.75 & 0.50 & 0.50 & 1 & 1 & 0 & 0 & 1.00 & 1 & 1 & 0 & 0.43 \\
\hline Sri Lanka & 0.70 & 0.70 & 0.25 & 0 & 0 & 1 & 0 & 0.50 & 1 & 0 & 0 & 0.29 \\
\hline Sweden & 0.60 & 0.60 & 0.10 & n.a. & 1 & 1 & 0 & 1.00 & 1 & 0 & 1 & 0.57 \\
\hline Switzerland & 0.67 & 0.67 & 0.67 & 1 & 1 & 1 & 0 & 0.75 & 1 & 0 & 0 & 0.29 \\
\hline Thailand & 0.75 & 0.75 & 0.75 & 1 & 0 & 1 & 0 & 1.00 & 0 & 1 & 0 & 0.29 \\
\hline Turkey & 0.75 & 0.75 & 0 & n.a. & 0 & 1 & 0 & 0.25 & 0 & 0 & 0 & 0.00 \\
\hline UK & 0.85 & 0.85 & 0.70 & 1 & 1 & 1 & 1 & 1.00 & 1 & 1 & 1 & 0.86 \\
\hline Uruguay & 0 & 0.50 & 0 & 0 & 0 & 0 & 0 & 0 & 0 & 0 & 0 & 0.00 \\
\hline USA & 0 & 0.95 & 0.95 & 1 & 1 & 0.5 & 0 & 1.00 & 1 & 1 & 1 & 0.71 \\
\hline
\end{tabular}




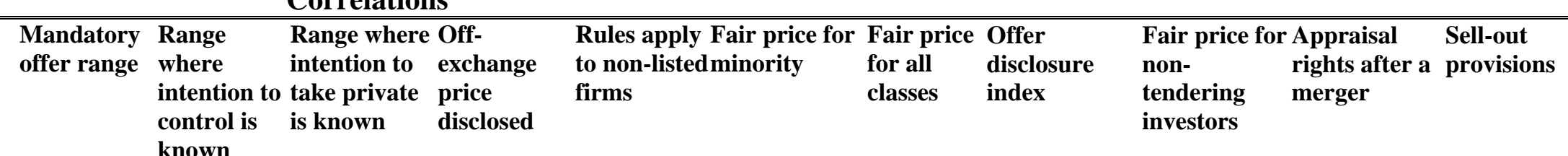

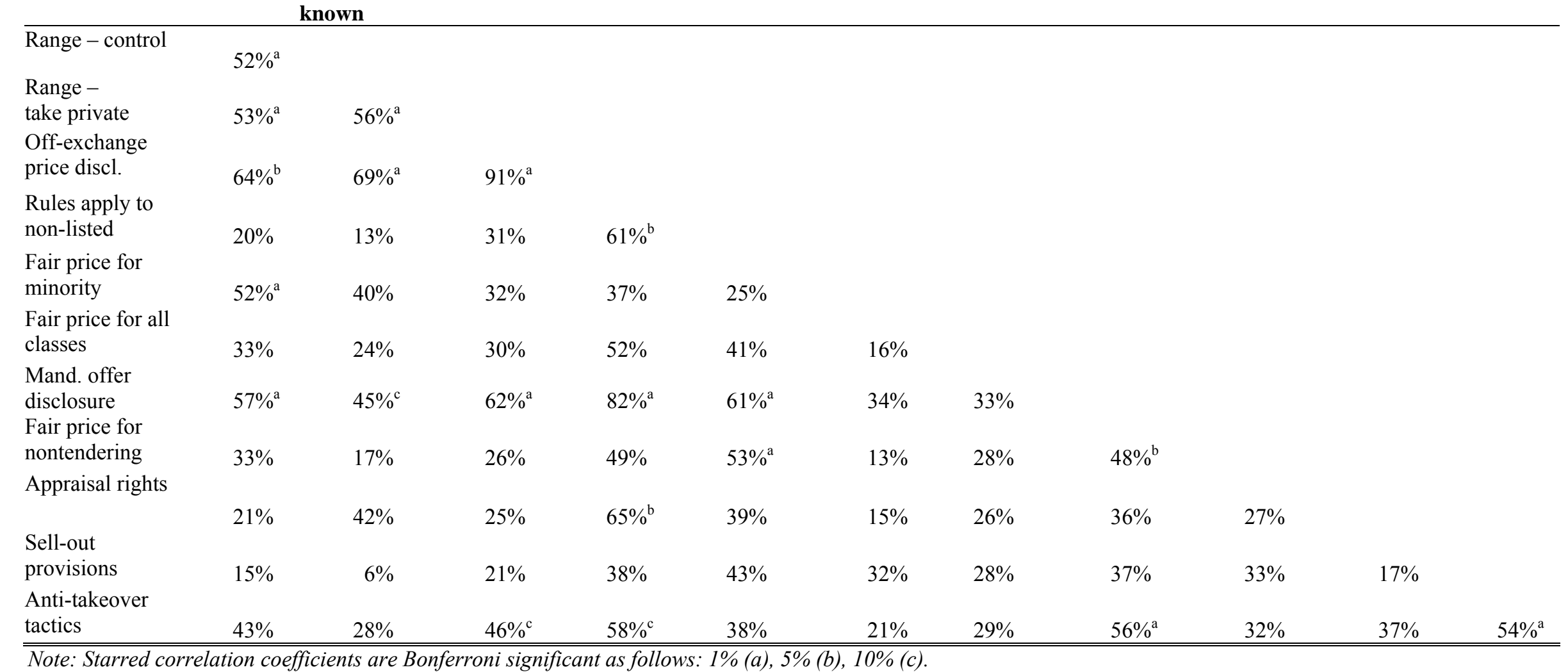

\section{Table 5 b}

\section{Correlations}

\begin{tabular}{|c|c|c|c|c|c|c|c|c|c|c|}
\hline & $\begin{array}{l}\text { Listed firms } \\
\text { to million } \\
\text { population }\end{array}$ & $\begin{array}{l}\text { Market cap of } \\
\text { stock exchange } \\
\text { to GDP }\end{array}$ & $\begin{array}{l}\text { Traded value of } \\
\text { stock exchange } \\
\text { to GDP }\end{array}$ & $\begin{array}{l}\text { Median } \\
\text { control value } \\
(\mathrm{D}-\mathrm{Z} \text { 04) }\end{array}$ & $\begin{array}{l}\text { Estmates } \\
\text { control value } \\
\text { (N 03) }\end{array}$ & $\begin{array}{l}\text { Takeover } \\
\text { premium } \\
\text { (R-V 04) }\end{array}$ & $\begin{array}{l}\text { Takeover } \\
\text { volume } \\
\text { (R-V 04) }\end{array}$ & $\begin{array}{l}\text { Hostile } \\
\text { takeovers } \\
\text { (R-V 04) }\end{array}$ & $\begin{array}{l}\text { Rule of } \\
\text { law }\end{array}$ & $\begin{array}{l}\text { Investor } \\
\text { Protection }\end{array}$ \\
\hline $\begin{array}{l}\text { Takeover } \\
\text { Index }\end{array}$ & $36 \%$ & $56 \%{ }^{\mathrm{a}}$ & $63 \%{ }^{\mathrm{a}}$ & $-35 \%$ & $-53 \%$ & $-23 \%$ & $55 \%{ }^{\mathrm{b}}$ & $53 \%{ }^{b}$ & $66 \%{ }^{\mathrm{a}}$ & $52 \%^{\mathrm{b}}$ \\
\hline
\end{tabular}

Note: Starred correlation coefficients are Bonferroni significant as follows: $1 \%$ (a), 5\% (b), 10\% (c).

Note: Data in Panel B from World Bank World Development Indicators, Dyck and Zingales (2004), Nenova (2003), Rossi and Volpin (2004), La Porta et al (1998). 
Table 6. The impact of takeover laws on capital markets and takeover activity

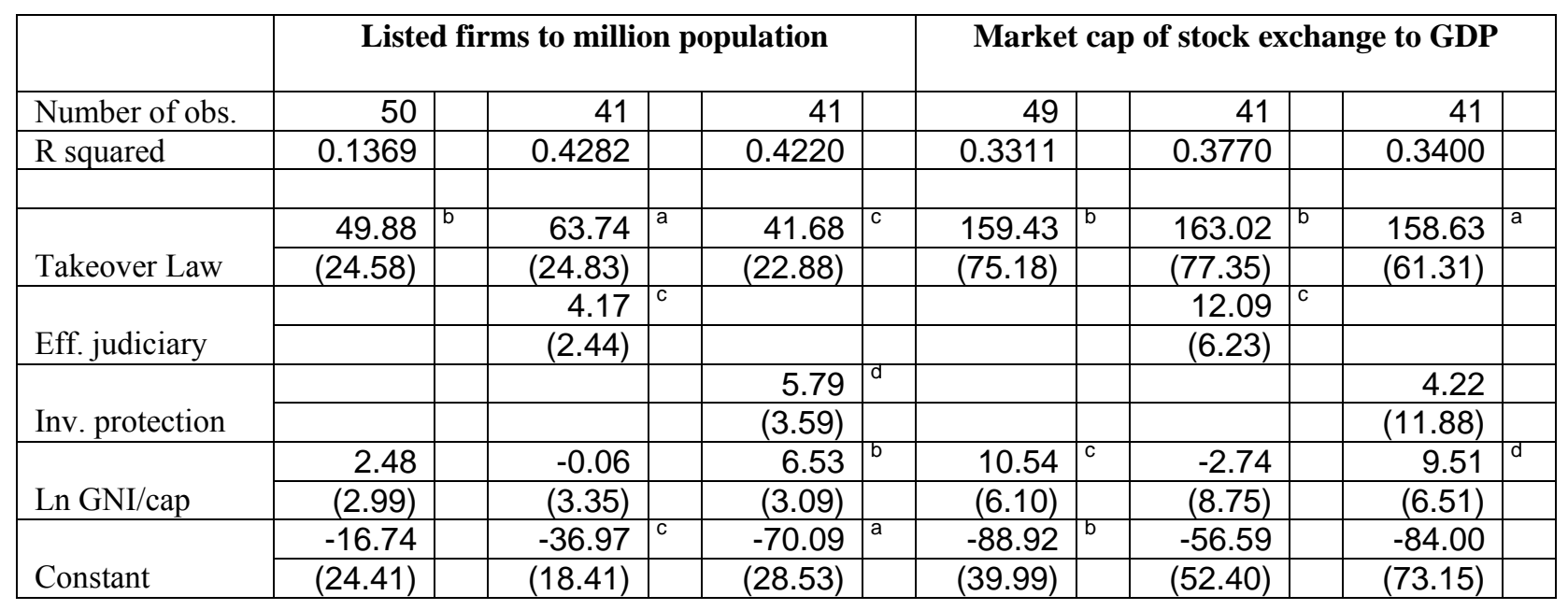

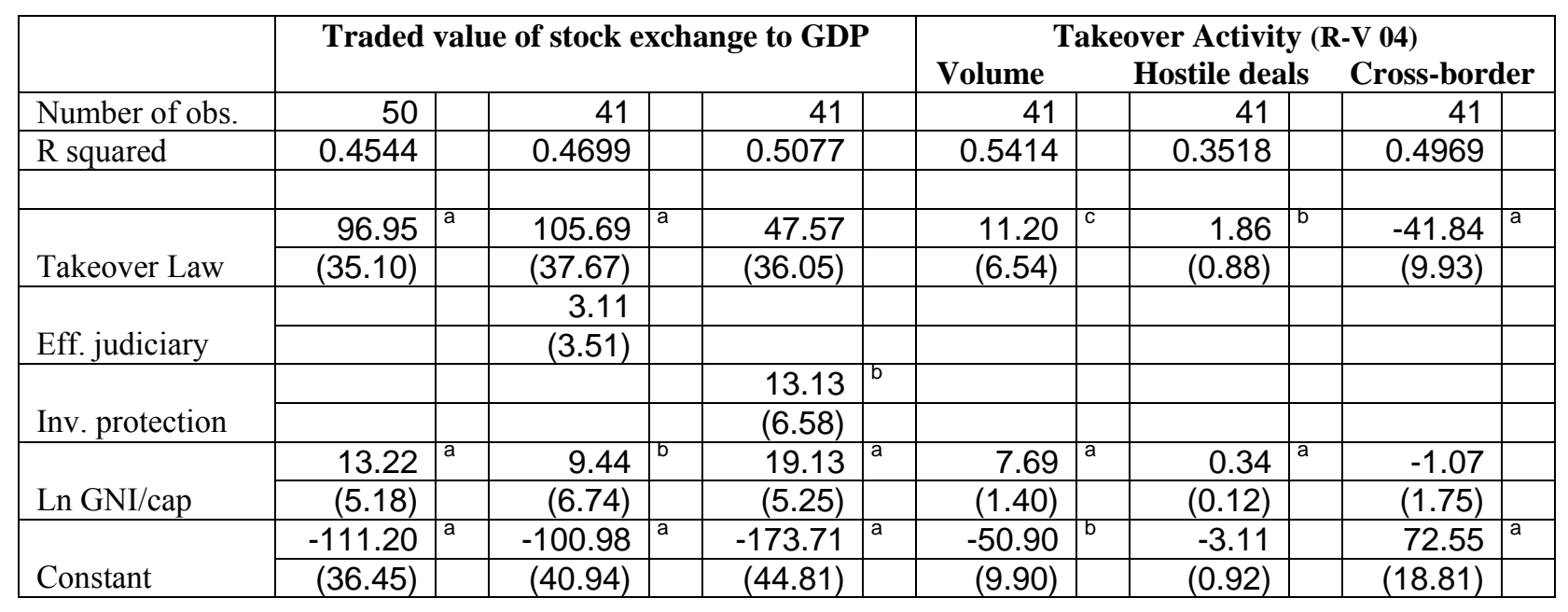

Note: Data from World Bank World Development Indicators and La Porta et al (1998). GNI is measured by the Atlas method. The measures of takeover activity are based on Rossi and Volpin (2004). Volume refers to the percentage of domestic traded companies targeted in completed deals ion the 1990s. Hostile deals is the share of attempted hostile takeovers as a percentage of domestic traded companies. Cross-border ratio is the number of cross-boarder deals as target as a percentage of all completed deals.

Significance levels are as follows: $1 \%(a), 5 \%(b), 10 \%(c), 15 \%(d)$. Regressions with robust standards errors. 
Table 7. The impact of takeover laws on the takeover premium

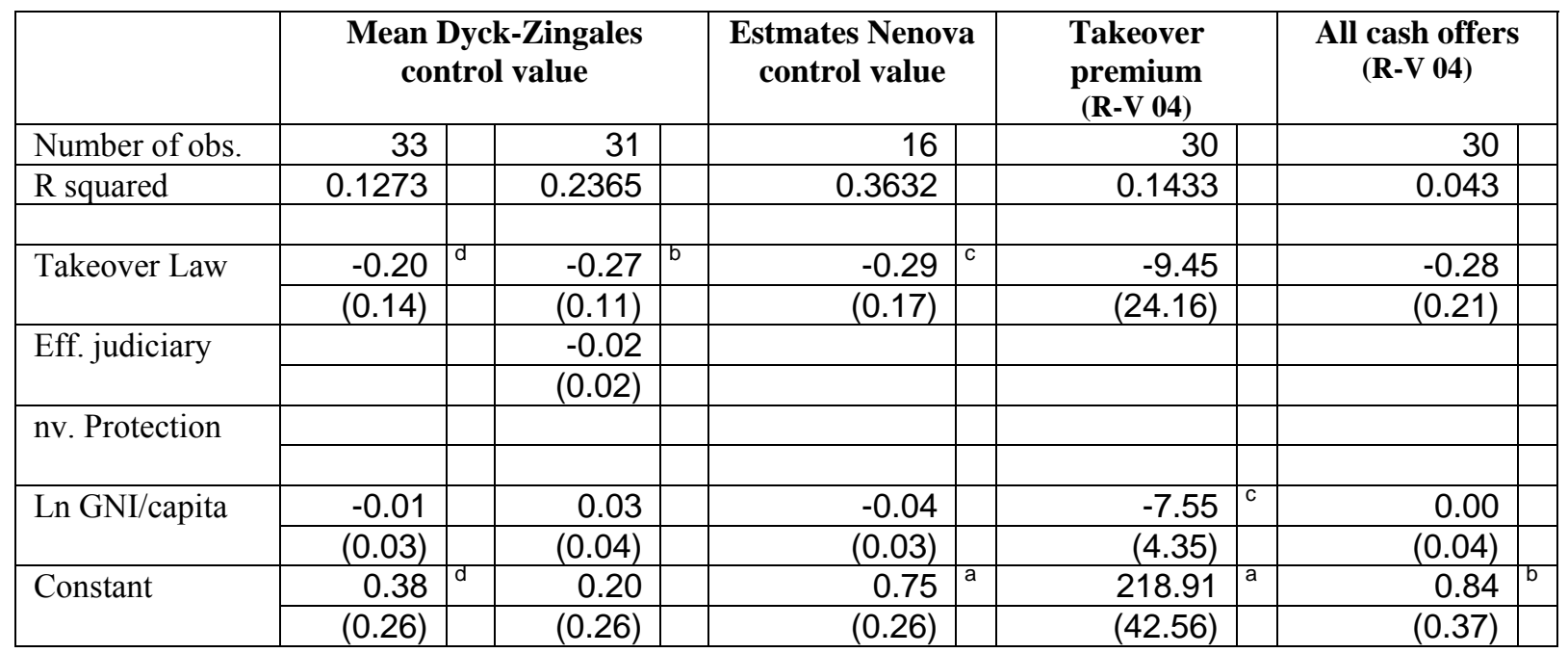

Note: Data from World Bank World Development Indicators, Dyck and Zingales 2004, Nenova 2003, Rossi and Volpin (2004), La Porta et al (1998). GNI is measured by the Atlas method. Takeover premium refers to the bid price as a percentage of the closing price of the target four weeks before the announcement. All cash offers is the share of merges and acquisitions paid for entirely in cash, out of all merger and acquisition deals.

Significance levels are as follows: $1 \%(a), 5 \%(b), 10 \%(c), 15 \%(d)$. Regressions with robust standards errors.

Table 8. Investigating other issues: labor laws or takeover barriers?

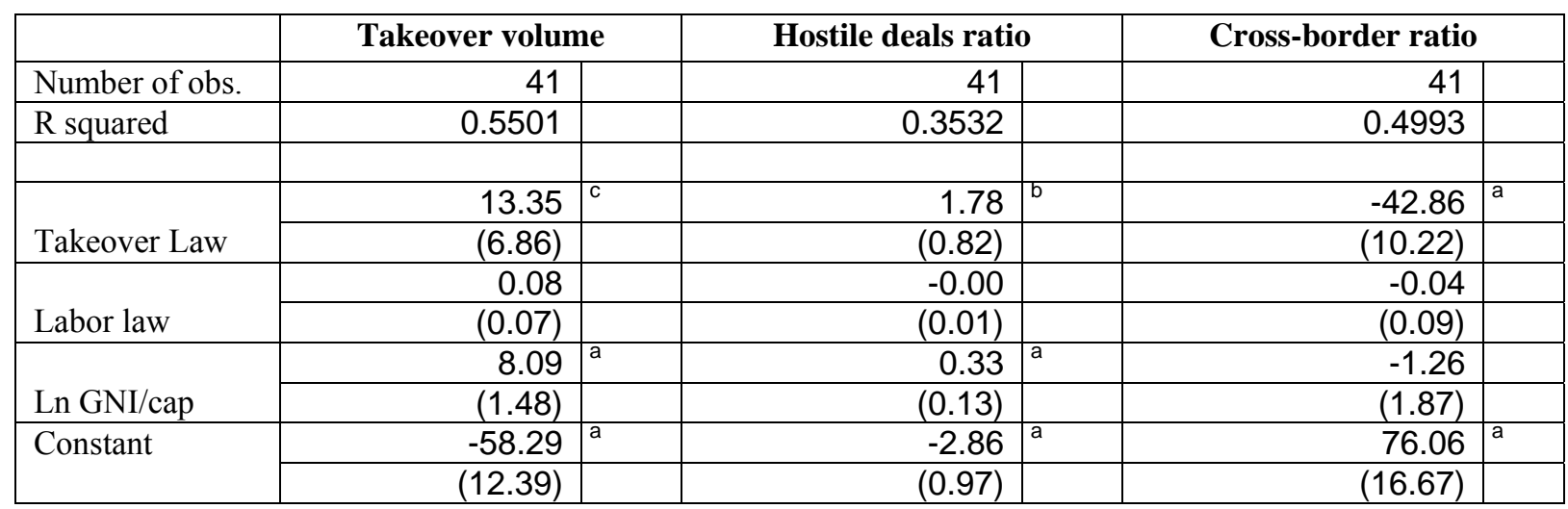

Note: Data from World Bank World Development Indicators, Doing Business Indicators, and Rossi and Volpin (2004). GNI is measured by the Atlas method. Takeover volume refers to the percentage of domestic traded companies targeted in completed deals ion the 1990s. Hostile deals ratio is the share of attempted hostile takeovers as a percentage of domestic traded companies. Cross-border ratio is the number of cross-boarder deals as target as a percentage of all completed deals. Labor law is proxied by the Doing Business 2006 measure of Difficulty of Firing.

Significance levels are as follows: $1 \%(a), 5 \%(b), 10 \%(c), 15 \%(d)$. Regressions with robust standards errors. 


\section{Appendix $A^{3}$}

Assume a stock market demand function of small investors $\mathrm{D}(\sigma, \mathrm{Y})$, where the quantity of shares demanded in the aggregate by investors is a function of their risk $\sigma\left(\mathrm{D}_{\sigma}{ }_{\sigma}<0\right)$, and their aggregate income $\mathrm{Y}\left(\mathrm{D}_{\mathrm{Y}}{ }_{\mathrm{P}}>0\right)$. Let the required return of investors for the level of risk that they have actually chosen be $\mu$ (there is an asset-pricing model in the background here). Let the value of all listed companies be $\mathrm{V}$, and the proportion going to minority shareholders be $\alpha$, so that the value due to minority shareholders is $\alpha \mathrm{V}$. Let B represent the value appropriated by controlling or dominant shareholders before observable income, so that the present value of all observable cash flows from all listed companies is (V-B). Note that now minority shareholders get:

$$
\alpha(\mathrm{V}-\mathrm{B})
$$

Now let us introduce a variable that will proxy the quality of investor protection regulation, $\gamma$. Let $\mathrm{B}$, the amount diverted from firm value, be distributed in function of the quality of investor protection regulation, $\gamma \varepsilon[0,1]$, i.e. $\mathrm{B} \sim$ $\mathrm{f}(\mathrm{B}, \gamma)$, where is the pdf. In other words, better legal protection decreases the value of B overall, across all possible outcomes of the probability distribution. One specific form of this function (that we will use here for simplicity), could be $\mathrm{f}(\mathrm{B}, \gamma)=$ uniform on $[0, \mathrm{~V}(1-\gamma)]$, so that for $\gamma=1$ we have $\mathrm{B}=0$ (no stealing when investors are well protected), and for $\gamma=0$ we have $B$ uniformly distributed on the interval $[0, \mathrm{~V}]$, with an expected value of V/2. Note the secularity of the distribution function of $\mathrm{B}$. First, $\mathrm{B} \leq \mathrm{V}$, i.e. the highest possible expropriation level is the entire value of the firm. Second, the strength of legal protection impacts not only the level of expropriation, but also its variance, i.e. the uncertainty that minority investors face in determining their returns is higher under weaker laws. We believe that this is a reasonable representation of reality.

Returning to the posited demand function by minority investors (1), note that the return to minority investors, given a one-year horizon, is:

$$
\mu \equiv(\mathrm{V}-\mathrm{B})_{\mathrm{t}} /(\mathrm{V}-\mathrm{B})_{\mathrm{t}-1}-1
$$

that is, the return on the investment of minority shareholders is in fact independent of the legal environment. This is a well-noted fact in the law and finance literature - rational investors anticipate the theft on an ex-ante basis, and therefore require a higher return in compensation for the expected future expropriation. In reality, one could argue that imperfect information and short-term horizons may in fact be responsible for near-rationality, thus precluding investors from perfect anticipation of expropriation, and introducing a negative relationship between return and quality of investor protection.

Thus we have:

Proposition 1: Minority investor return is not affected by poor laws, assuming perfect information and infinite horizons. Failing these assumptions, minority investor return will be negatively associated with investor protection quality.

Note, however, that although return is unaffected (with assumptions) by poor laws, the variance of stock returns is. Specifically, since the variability of B increases the poorer the laws are, and since $\mu \equiv(V-B)_{t} /(V-B)_{t-1}-1$, we see that $\sigma$ is higher in the presence of less protective laws. Thus we have:

Proposition 2: The variability of minority investor return increases with poor laws.

Trivially from propositions 1 and 2, we have:

Proposition 3: $D_{\gamma}^{\prime}>0$, i.e. investor demand increases with better protection of minority shareholders.

In other words, we have hypothesis $1^{4}$ :

Breadth and depth of stock markets decrease with poorer investor protection, in particular with poorer protection of investor returns during takeovers.

\footnotetext{
${ }^{3}$ The discussion under this heading is a formalization of the central argument of the law and economics literature, e.g. "Legal Determinants and External Finance", La Porta et al. (1997), Journal of Finance.

${ }^{4}$ Strictly, we need to assume an infinitely elastic supply of shares (demand for financing), a standard assumption on corporate finance.
} 


\section{Appendix B A summary of the key provisions of Directive 2004/25/EC on Takeover Bids}

Mandatory offer to all voting securities at an equitable price, following acquisition of control. Control is defined by each member state. The directive does not oblige the offer to be extended to limited and non-voting securities, but directs the member states to have such a provision. Partial bids for stakes smaller than a controlling stake are also left to the regulation of member states. (Article 5.1)

Pricing should be equitable within security classes, but not between classes. Equitable price is the average market price in the prior 6 to 12 months, or the highest price paid during the bid, whichever is higher. The consideration can be cash or securities; in the case of illiquid or non-traded securities, and when at least $5 \%$ of the shares were purchased for cash during the offer, a cash option becomes mandatory. (Article 5.5)

Tender offer notice and offer document to the public and the regulator is required. The offer document contains the terms of the bid; the identity of the offeror (no ownership information); type and amount of securities targeted; consideration and a justification for determining the value; compensation offered due to breakthrough rule; holdings of offeror and persons acting in concert; all conditions of the bid; the offeror's intentions; the offer acceptance period; information on financing of the bid; identity and relationships of persons acting in concert with the offeror and target companies. (Article 6.3)

The target board opinion should be published. (Article 9.5)

Disclosure: Companies should publish information on their capital structure; restrictions on share transfers; significant direct and indirect shareholdings (including through pyramids and cross-shareholdings); special / golden shares; the system of control of any employee scheme; any restrictions on voting rights; shareholder agreements; the rules governing amendments of articles and appointment / replacement of directors; powers of directors, specifically to buy-back and issue shares; any agreements that become effective upon a change in control (e.g. poison pills); any severance pay that becomes effective upon a takeover bid (e.g. golden parachutes). (Article 10)

Offer procedure: The directive urges member states to regulate the tender offer period, between 2 and 10 weeks from the publication of the offer document. (Article 7) Member states should also regulate the rules for competing bids, the lapsing of bids, the revision of bids, disclosure of bid results, and irrevocability of bids and conditions permitted. (Article 13)

Breakthrough: Transfer restrictions become void during takeover bids. (Article 11.2) Voting caps become void and multiple-voting shares receive one vote when AGM votes on anti-takeover measures. (Article 11.3) If a takeover bid results in $75 \%$ of the shares, all special rights and board election restrictions become void. (Article 11.4) The application of these rules is optional for companies, at the choice of member states or companies. (Article 12.1)

Squeeze-out and sell-out rules: The directive urges member states to adopt squeeze-out and sell-out provisions in takeovers, at a fair price, upon the acquisition of between 90 and $95 \%$ of the shares. The rules can be by class, and need not concern all classes of shares. (Articles 15 and 16)

Any anti-takeover actions of the target board following the public announcement of the bid (but not before, so for example not any action since the board has become aware of the bid) must be approved by the AGM. Any decisions out of the ordinary course of business are to be approved by the AGM anyway. (Article 9) The application of this rule is optional for companies, at the choice of member states or companies. (Article 12.1)

Restrictions on transfer of shares, voting caps, extraordinary appointment rights and multiple-voting rights are suspended during the bid and for the first AGM following the bid. 


\section{Appendix C A look at current takeover regulations in Chile}

Early warning. Chile has reasonable early warning disclosure rules. All shareholders with $10 \%$ of the stock must report within 2 days of buying or selling shares in the corporation. Insiders who own $10 \%$ of the stock report monthly, within the first 5 days of the month. Reporting is to the securities regulator and the exchange, which in turn make the information public. Large shareholders are required to state their intention to take over the company. Further intentions to take the company private should be declared in the tender offer prospectus.

Mandatory offers and pricing. A tender offer is an offer made to the public for a given stake in the company. Nonlisted companies are not subject to tender offer rules. The offer can be partial, and acquisitions of $5 \%$ or less may be exempted from the public offer requirements. An acquisition that intends to purchase control must be made via the procedures of a tender offer (private deals can be concluded off the market, as well). Upon crossing

$66.7 \%$ ownership threshold, an owner needs to tender publicly for all outstanding voting shares (mandatory offer). The price of the tender offer cannot be lower than the highest price paid for the shares in the 90 days prior to the offer. The consideration (payment) for shares tendered may consist of cash or publicly offered securities. ${ }^{1}$ Holders of different kinds of shares may be offered different prices. Shareholders who did not tender during the offer, but changed their mind after seeing the offer results, have access to the same terms and conditions for a further 30 days after the offer expires. In sum, not all minority shareholders receive the same price, but within the class, shares are treated equally, and offer prices are compatible with market conditions.

Tender offer notice. The acquirer issues a prospectus to the public, containing the price and conditions under which the transaction will be carried out. The prospectus contains a description of the securities that are the object of the tender offer; the minimum share the bidder aims to buy; the price and payment terms; details on the tender period and procedure; information on the financing of the acquisition; a full identification and general information on the bidder, its ultimate controllers and their respective businesses; details on the bidder's current ownership in the target company. Past relationships between the bidder and target need not be disclosed, and an analysis of the impact of the acquisition on the bidder's shareholders, is not mandated either.

The bidder must announce the offer in 2 newspapers of national circulation, at least 10 business days in advance. Within 2 days of the announcement, the target company must provide the acquirer with a list of all shareholders. Within a further 3 days, each of the directors of the target must issue to the public a written report assessing the merits of the offer for the company's shareholders, and noting his/her relationship, if any, with the acquirer.

Tender offer procedure. A tender offer is open for 20 to 30 days, and can be extended by 5 to 15 days. This renewal must be communicated to all interested parties before the expiration of the initial period through a notice published in the same newspapers in which the original notice was published. Once announced, a tender offer cannot be withdrawn by the bidder unless this is specifically provided for in the prospectus and in the public notice. The bidder also cannot change the terms of the tender offer, except to increase the price or the number of shares sought. Any increase in price must benefit the shareholders that have tendered their shares at the original price. Shareholders, on the other hand, can withdraw their tendered shares at any time while the offer is open.

Share purchases by the acquirer on the open market during the offer are prohibited. During the tender offer period, competing tender offers may be launched by publishing a notice at least 10 days prior to the expiration of the ongoing tender offer. The original bidder cannot participate in the competing tender offer.

Rules applicable following the offer. Within 3 days after the expiration of the offer, the bidder must publish the total number of shares tendered, the number of shares that it will acquire, the pro rata factor if applicable, and the controlling percentage that it will achieve as a consequence of the offer. For 30 days after the offer is closed, the bidder must stand ready to purchase any additional shares from investors who did not tender during the offer period, at the offer price. For 120 days after the offer, if the acquirer pays a higher price for the shares, all tendered shares are entitled to receive that higher price. For 12 months following the offer, the acquirer may not buy more than 3\% of the stock in the target company, without a tender offer at the price of the initial tender offer.

Aggrieved shareholder recourse. Aggrieved shareholders in a company whose majority shareholder holds $2 / 3^{\text {rds }}$ of the stock have the right to exercise their appraisal rights and to have their shares bought by the majority shareholder, at market value. The law defines market value as the average price of the 2 preceding months for actively trading stock, and book value otherwise. Similar appraisal (withdrawal) rights are given following a merger, major asset sales, or a decision to take the company private, to shareholders who dissented at the shareholder meeting where the corresponding decision was taken.

Rules for taking the company private. A company can be taken private with the agreement of $2 / 3^{\text {rds }}$ of the votes. Squeeze-outs are not allowed under Chilean law - the controlling shareholder may not oblige investors to tender their shares against their will. Dissenting shareholders have appraisal rights in this case. Taking private, sell-out and buy-back provisions are stipulated in the Corporations Act, which applies to public and closed companies. 
Allowable anti-takeover mechanisms. Chilean tender offer provisions generally prohibit a target company from taking frustrating action during the tender offer period. However, some mechanisms which can potentially be used to fend off a takeover are allowed. For example, there is no obstacle for issuance of shares during the tender offer, though there are limits on increasing debt during a tender offer. Target companies are banned from acquiring their own shares, and of disposing of more than $5 \%$ of their assets. More sophisticated anti-takeover tactics, such as poison-pills or preferred stock issuance with redemption rights during a control change are not used. They are not forbidden by law, but would require a general shareholder meeting approval, and may face a review by the securities regulator, on the legal concern of being "detrimental to the interests of the corporation and its shareholders". Golden parachutes would be objectionable on the same count.

Public corporations whose shares are eligible for investment (up to a certain percentage provided for in the Pension Funds Act) by Chilean pension funds are subject to certain restrictions which, in practice, may operate as antitakeover devices, such as a voting cap of $65 \%$, or minimal float requirements. Shares of public companies are freely transferable by law. Foreign investors are not restricted in any way, but some rules do exist for non-resident investment funds. Finally, some companies have issued class shares with varying rights to elect board members, sometimes with a cap on individual ownership. Such capital structures prevent the efficient function of the market for corporate control, and may shield management from accountability. 


\section{Appendix D}

\section{Takeover regulations - questionnaire}

1. What are the relevant laws regulating the market for corporate control in the country?

2. Please answer relative to open market purchases:

a. Ownership threshold(s) at which disclosure of ownership is required?

b. What is the deadline to disclosure (days after crossing threshold)?

c. Is disclosure of intention to acquire control required?

d. Is disclosure of price at which shares are acquired mandated?

e. Authorities to which it is disclosed (securities regulator, exchange, issuer, other)?

f. Is disclosure publicly available (web, publication, posted in a public place)?

3. Please answer relative to purchases negotiated off the market (or on the "second floor"):

a. Are block purchases off the market allowed? Up to what block size?

b. Is disclosure of ownership threshold (size of block exchanged) required?

c. Is disclosure of intention to acquire control required?

d. Is disclosure of price at which shares are acquired mandated?

e. Authorities to which it is disclosed (SEC, exchange, issuer, other)?

f. Is disclosure publicly available (web, publication, posted in a public place)?

4. Please answer relative to a friendly merger / acquisition:

a. Do all classes vote?

b. What is the percentage approval required?

c. Do dissenting / abstaining shareholders receive withdrawal rights?

5. Do the rules for public offers (or some public offers, e.g. mandatory, partial, or an offer with the aim to take the firm private) apply to private (non-listed) firms as well?

6. Please answer relative to partial tender offers:

a. What is the ownership threshold beyond which a public offer is the only means to acquire shares?

b. Are partial offers allowed? If they're only allowed under a certain ownership threshold, what is it?

c. Is pro-rating mandatory in case of oversubscription?

d. Are share purchases by the acquirer on the side allowed during the offer?

7. Please answer relative to mandatory tender offers (if the law provides for one):

a. What is the ownership threshold beyond which a public offer is obligatory (even if the owner does not want to buy more shares)?

b. Does the offer have to be for all shares? If not, what is the minimum share of stock that the buyer needs to be prepared to purchase?

c. Does the mandatory offer have to include all classes of shares (including non-voting classes)?

d. Are share purchases by the buyer allowed on the side during the offer?

e. Is approval required for the tender offer? If yes, by whom (SEC, exchange, issuer shareholders, issuer management, other)? Is approval tacit?

f. Can any governing body prohibit the offer? If yes, are there clear rules as to the circumstances when the offer can be prohibited?

g. Do employees / their representatives/unions have a say in the matter?

h. Do shares need to be deposited?

i. Can shares be withdrawn before the end of the offer, even if there was no change in terms?

j. Can the offer (specifically the quantity sought or the consideration) be changed after the notice is published? If yes, is it mandatory to extend it as a result of the change? Is there mandatory disclosure of the change?

8. Disclosure regulations during mandatory offers (of the law fails to provide for one, please answer with respect to general tender offer rules, if any):

a. Whom does the disclosure go to (SEC, exchange, issuer, other)?

b. Is disclosure publicly available (web, publication, posted in a public place)?

c. What is the deadline for filing information about the offer (days before the offer becomes effective)?

d. Does the bidder have access to the stockholder lists of the target and their security position?

e. What are the mandatory contents of the disclosure:

i. total number and class of securities sought;

ii. proof of sources of financing for the offer;

iii. plans for the future of the company (plan to control, to take private);

iv. type and amount of consideration offered to security holders;

v. past contacts, transactions, and agreements between acquirer and target;

vi. current acquirer interest in securities of target;

vii. the identity of the bidder (ultimate ownership, related parties in same industry); 
f. Can security holders obtain the full disclosure materials promptly (within how many days)? Is it at the bidder's expense?

g. What are the restriction on the timing of the offer:

i. start date of offer (number of days after the public announcement);

ii. end date of offer (number of days after the start date)

iii. start date of acceptance period (number of days after the start date)

iv. end date of acceptance period (number of days after the start date)

v. start date of withdrawal rights (number of days after the start date)

vi. end date of withdrawal rights (number of days after the start date)

h. Consideration for the offer:

i. Which types of consideration are allowed: cash, listed securities on major exchange, OTC securities, other?

ii. Does the public offer necessarily have to include a cash option?

iii. Are there any restrictions on the price of the offer (relative to economic or accounting value, or past prices, etc)

iv. Can non-tendering shareholders be bought out at the same terms as the public offer after the end of the offer? For how long thereafter?

i. Results of the offer:

i. Is the percentage of securities deposited disclosed? How soon after the end day of the offer?

ii. Can the offer be made conditional on a certain percentage acceptance?

iii. Is the offer conditional on a certain level of acceptance by law?

iv. Are subsequent offers blocked under certain conditions?

v. Are subsequent purchases limited to a particular price; for how long following an offer; any limitations on quantity; on type of consideration (need it be the same as before, etc.). If there is a second offer at a higher price, do the shareholders who tendered to the first offer get compensated?

9. Allowable takeover defenses:

a. Is the target allowed to issue shares during the tender offer? Can they be without preemptive rights?

b. Is the target allowed to buy back shares during the tender offer?

c. Is the target allowed to have major asset sales during the tender offer?

d. Percentage shareholder approval needed to dismiss a director (any additional requirements for the dismissal?)

e. Coattail provisions mandatory at change of control?

f. Foreign ownership restrictions by law?

g. Are staggered boards allowed by law?

h. Are voting caps allowed by law?

i. Can the board restrict the transferability of shares?

j. Are golden shares allowed?

k. Are poison pills allowed?

10. Rules for taking the company private:

a. Do all classes vote on the taking private decision at the annual shareholder meeting? What is the percentage approval required?

b. What are the limits on the price to be paid when the company is being taken private, if any?

c. Can shareholders have an independent appraisal of their shares at the company expense? Any other appraisal rights?

d. What are the associated disclosure rules when taking the company private?

11. Sell-out / squeeze-out provisions:

a. What is the percentage at which shareholders have the right to be bought out by the majority owner?

b. Are there any restrictions on the price at which shareholders can sell their shares?

c. What is the percentage at which the majority owner has the right to squeeze-out the minority?

d. Are there any restrictions on the price at which the majority owner has the right to squeeze-out the minority?

12. Buy-back rules:
a. Do all classes vote on the taking private decision at the annual shareholder meeting? What is the percentage approval required?
b. Are there any limits on the quantity of shares that can be bought back into treasury? Any limits on the price to be paid? Any limits as to the amount of time the shares can be kept in treasury before being re- sold or cancelled?
c. What are the associated disclosure rules when buying-back shares? 


\section{Appendix $E$}

\section{Data sources for takeover laws}

\begin{tabular}{|c|c|}
\hline Country & Sources \\
\hline All countries & LEXUS - NEXUS, Economist Intelligence Unit, International Securities Services Association. \\
\hline \multirow[t]{2}{*}{ Argentina } & Capital Markets Transparency Decree 677/2001, General Resolution No.330/19999 \\
\hline & Stock Exchange Regulator: Argentinean National Securities Commission \\
\hline \multirow[t]{3}{*}{ Armenia } & Civil Code 1998, the Law on Joint-Stock Companies 2001, Securities Market Regulation Law \\
\hline & 2000, the Securities Market Rules of Regulation. \\
\hline & Stock Exchange Regulator: Securities Commission of Armenia \\
\hline \multirow[t]{3}{*}{ Azerbaijan } & Corporate Law (Civil Code articles 98-134), Securities Law (Articles 987-997 and 1078 of the \\
\hline & Civil Code), Law on Protection of Investor Rights on the Stock Market 2000. \\
\hline & Stock Exchange Regulator: State Commission for Securities \\
\hline \multirow[t]{2}{*}{ Australia } & Corporations Law 1991, Part 6; Trade Practices Act \\
\hline & Stock Exchange Regulator: Australian Securities Commission \\
\hline \multirow[t]{2}{*}{ Austria } & Stock Exchange Law (1989, amended 2001), Take-over Act (1999) \\
\hline & $\begin{array}{l}\text { Stock Exchange Regulator: Council of the Vienna Stock Exchange and State Comissioner } \\
\text { (Wiener Borsekammer, Borsecommissar), Austrian Financial Market Authority (since 2002); } \\
\text { Takeover Commission }\end{array}$ \\
\hline \multirow[t]{2}{*}{ Belgium } & $\begin{array}{l}\text { Law on disclosure of large shareholding in companies listed on the stock exchange and public } \\
\text { take-over bids (1989), Royal Decree on public take-over bids and changes in control over } \\
\text { companies (1989) }\end{array}$ \\
\hline & Stock Exchange Regulator: Banking and Finance Commission \\
\hline \multirow[t]{2}{*}{ Brazil } & $\begin{array}{l}\text { Brazilian Corporation Law 6404/1976, Law } 6385 \text { (1976) establishing CVM as the supervisory, } \\
\text { regulatory agency of publicly owned companies and the various stock exchanges, Law } \\
4728 / 1965 \text { regulating Capital Markets. }\end{array}$ \\
\hline & Stock Exchange Regulator: Securities and Exchange Commission of Brazil \\
\hline \multirow[t]{2}{*}{ Bulgaria } & Law on Public Offering of Securities 2001 \\
\hline & Stock Exchange Regulator: Commission for Financial Supervision \\
\hline \multirow[t]{2}{*}{ Canada } & $\begin{array}{l}\text { State Securities Acts: Ontario 1987, Quebec 1987, British Columbia 1985, Manitoba 1988, } \\
\text { Alberta 1988, }\end{array}$ \\
\hline & $\begin{array}{l}\text { Stock Exchange Regulator: Provincial securities commissions, which must try to maintain } \\
\text { harmonious regulations among all provinces. }\end{array}$ \\
\hline \multirow[t]{2}{*}{ Chile } & Law 18.045 on the Securities Market, Law 19.705 on Public Offer for Acquisition of Shares \\
\hline & Stock Exchange Regulator: Chilean Securities and Insurance Supervisor. \\
\hline \multirow[t]{2}{*}{ China } & Securities Law of the People's Republic of China, June 6, 1999 \\
\hline & Stock Exchange Regulator: China Securities Regulatory Commission. \\
\hline \multirow[t]{3}{*}{ Colombia } & Commercial Code (amended by Law 222 of 1995), Financial Framework Law 35 (1993), \\
\hline & Law 446 (1998), Resolutions 400 and 1200 (1995), Resolution 275 (2001). \\
\hline & Stock Exchange Regulator: Supervalores \\
\hline \multirow[t]{2}{*}{ Czech Rep. } & Commercial Code. \\
\hline & Stock Exchange Regulator: Czech Securities Commission. \\
\hline \multirow[t]{4}{*}{ Denmark } & Stock Exchange Act (Consolidate Act 26 (92), amended by Act 452 (93), Securities Centre Act \\
\hline & (Consolidate Act 101 (92), amended by Act 149(93), Commerce and Companies Agency Act \\
\hline & (1987), Securities Trading Act, consolidated 2001, Part 8 “Take-over Bids” \\
\hline & Stock Exchange Regulator: Danish Financial Supervisory Authority (Finanstilsynet) \\
\hline \multirow[t]{2}{*}{ Ecuador } & Ley De Mercado De Valores 107. \\
\hline & Stock Exchange Regulator: Superintendencia de Compañias (Consejo Nacional de Valores) \\
\hline \multirow[t]{2}{*}{ Egypt } & Capital Market Law (1992), Executive Regulations of the Capital Market Law (1992) \\
\hline & Stock Exchange Regulator: Capital Market Authority \\
\hline \multirow[t]{3}{*}{ Finland } & Finnish Companies Act (734/1978), Securities Market Act (465/1989), amended by 2002 \\
\hline & Rules of the Helsinki Stock Exchange (2002). \\
\hline & Stock Exchange Regulator: Financial Supervision (Rahoitustarkastus). \\
\hline France & $\begin{array}{l}\text { Title } 5 \text { of the General Regulations, Committee for Stock Exchange Transactions, Rule 2002-04 } \\
\text { relating to public tender offers, Rules } 98-07 \text { relating to public disclosure requirements and 88-02 }\end{array}$ \\
\hline
\end{tabular}


pertaining to securities markets (1988), modified 1989, Government decree 88-254 (1988), modified 1989.

Stock Exchange Regulator: Stock Exchange Counsil (Conseil des Bourses de Valeurs)

Germany Takeover Code (2002), Securities Trading Act (1998 as amended by 2001), Stock Corporations Act, section 305, Borsengesetz (Exchange Law) (1896), revised 1989, Borsenaufsichtsbehorde 1,2 (1) of the Exchanges Act, 3 of Rules and regulations of the Frankfurt Stock Exchange. Stock Exchange Regulator: Federal Financial Supervisory Authority

Ghana Companies Code 1963 (Act 179); Industry Law 1993 (PNDCL 333); the Securities Industry (Amendment) Act 2000 (Act 590); SEC Regulations 2003 (LI 1728).

Stock Exchange Regulator: Ghana Securities and Exchange Commission.

Greece Rule 1/195/ on Tender Offers in the Capital Market for the Acquisition of Securities (2000) Stock Exchange Regulator: The Capital Market Commission

Hong Kong Hong Kong Code for Takeovers and Mergers 1975 and amendments by 2002, Companies Ordinance, Securities Ordinance, Securities and Futures Commission Ordinance, Stock exchanges unification ordinance, Rules of the exchange.

Stock Exchange Regulator: Securities and Futures Commission.

India Securities Contract Act (1956), Substantial Acquisition of Shares and Takeovers Regulations (1997 as amended by 2002), Buy Back of Securities Regulation (1998)

Stock Exchange Regulator: The Securities and Exchange Board of India

Indonesia Capital Market Law (1995), Bapepam Rules relating to tender offers, mergers and takeovers, disclosure

Stock Exchange Regulator: Indonesian Capital Market Supervisory Agency (Bapepam)

Israel Securities Law, 5728-1968, amended by 2002, Securities (Purchase Offer) Regulations (2000) Stock Exchange Regulatory: Israel Securities Authority

Italy Law 149/1992, Decree 58 of 1998, Part IV, Regulation 11971 of 1999, Part II and III on public tender offers, mergers, and disclosure

Stock Exchange Regulator: Stock Exchange Council (Consiglio di Borsa, under CONSOB Commissione Nacionale per le Societa e la Borsa).

Japan Securities and Exchange Law (1948, amended by 1992), Ordinances on disclosure with respect to tender offer of share certificates (amended by 1999)

Stock Exchange Regulator: The exchange is self-regulated.

Jordan Company Law 22 of 1997; Jordan Securities Law.

Stock Exchange Regulator: Jordan Securities Commission.

Kenya Capital Markets Act, Capital Market (Takeovers and Mergers) Regulations (2002), Regulations on Public Offers, Listing and Disclosure (2002)

Stock Exchange Regulator: Capital Market Authority

Korea (Rep. Securities and Exchange Law (1962 as amended by 2001), Chapter IV, and 1991 amendment,

of) Law on Fostering the Capital market, Securities Investment Trust Business Law, Securities and Exchange Commission Rules.

Stock Exchange Regulator: Financial Supervisory Service

Lithuania Law on Public Trading in Securities (2001), Company Law (2000), Rules on Submission, Registration and Execution of a Tender Offer (2002), Rules on Disclosure of Information about Acquisition of a Block of Shares (1998), Rules on Execution of the Tender Offer on the Stock Exchange (2001)

Stock Exchange Regulatory: Lithuanian Securities Commission

Malaysia $\quad$ Securities Commission Act (1993), Part IV, Code on Takeovers and Mergers (1998)

Stock Exchange Regulatory: Securities Commission

Mexico Corporation Law, Commerce Code, Securities Market Act.

Stock Exchange Regulator: National Securities Commission

Netherlands Act on the Supervision of the Securities Trade (1995), Decree on public offers of securities (2001), Disclosure of Major Holdings in Listed Companies Act (1996), Rule 01-02 on the offer document

Stock Exchange Regulator: The Netherlands Authority for the Financial Markets.

Nigeria Investment and Securities Act No.45 of 1999, Companies and Allied Matters Act of 1990 Stock Exchange Regulator: Securities and Exchange Commission 
Pakistan Ordinance on substantial acquisition of shares and takeovers of listed companies (2000), Companies (buy-back of shares) rules (1999)

Stock Exchange Regulator: Securities and Exchange Commission of Pakistan

Peru Ley General de Sociedades, 1997; Ley del Mercado de Valores 1996.

Stock Exchange Regulator: Comisión Nacional Supervisora de Empresas y Valores

Philippines Securities Regulation Code (2000), Chapters 5, 6, Rule 18.1 on disclosure, Rule 19.1 on tender offers.

Stock Exchange Regulator: Securities and Exchange Commission

Poland Commercial Code; Law on Public Trading in Securities.

Stock Exchange Regulator: Polish Securities \& Exchange Commission

Romania Company Law 31/1990; Capital Market Law 297 of 2004.

Stock Exchange Regulator: Comisia Naţională a Valorilor Mobiliare

Singapore Companies Act (amended by 1998), Securities Industry Act (2000), Securities Industry

Regulations, Securities and Futures Act (2001), Part VIII, Singapore Code on Takeovers and Mergers (2002)

Stock Exchange Regulator: Monetary Authority of Singapore

South Africa Companies Act 1973, amended 1989: sections 314 to 321, Chapter XV and XV, and section

440C of the amended act, Securities Regulation Code on Takeovers and Mergers 1991, Rules of the Securities Regulatory Panel 1991, Stock Exchanges Control Act 1 (1985), Rules and

Directives of the exchange.

Stock Exchange Regulator: Stock Exchange Committee.

Spain Securities Market Law 1988, amended 2002

Stock Exchange Regulator: Comisión Nacional del Mercado de Valores

Sri Lanka Company Takeovers and Mergers Code 1995, SEC Rules on disclosure and listing and delisting requirements (2001),

Stock Exchange Regulator: Securities and Exchange Commission of Sri Lanka

Sweden Industry and Commerce Stock Exchange Committee Takeover Standard, Financial Instruments Trading Act (980/1991), Swedish companies Act (1975:1385), Financial Instruments Trading Act (1991:980), Securities Business Act (1991:981) Share Accounts Act (1989:827).

Stock Exchange Regulator: Financial Supervisory Authority.

Switzerland Code of Behavior for Public Takeover Bids, Association of Swiss Exchanges, Revised Swiss

Code of Obligations 1992, Securities Trading Law 1912 for Zurich, Stock Exchange Law 1944, amended 1982 for Basle, Stock Exchange Law 1856, amended 1958,1959 for Geneva.

Stock Exchange Regulator: Stock Exchange Committee.

Thailand Securities and Exchange Act, Chapter 8 Unfair Securities Trading Practices and the Acquisition of Securities for Business Takeovers, 1992

Stock Exchange Regulator: Securities and Exchange Commission.

Turkey $\quad$ Capital Market Law (1991), Official Gazette 18537, 1984, Regulation on Proxy Voting, Proxy

Solicitation and tender Offers 1996, Regulation on Public Disclosure 1995

Stock Exchange Regulator: Capital Markets Board.

United Companies Act 1989, City Code on Takeovers and Mergers, Financial Services and Markets

Kingdom Act 2000, Schedule 11, Rules governing Substantial Acquisition of Shares

Stock Exchange Regulator: Financial Services Authority

United States Securities Act of 1933, Securities Exchange Act of 1934, Regulation 13D-G: Securities ownership, Regulation 14D: Disclosure Requirements and Minimum Time for Tender Offers, Regulation 14E: Tender Offer Rules, Regulation M-A: Mergers and Acquisitions, Rule 13e-3: Going Private Transactions, Rule 13e-4: Tender Offers by Issuers, Schedule TO: Tender Offer Statement under Section 14(d)(1) or 13(e)(1) of the Securities Exchange Act of 1934, Delaware General Corporation Law

Stock Exchange Regulator: U. S. Securities and Exchange Commission

Uruguay Ley de Sociedades Comerciales \# 16,060 of 1989; Ley de Mercado de Valores \# 16,749 of 1996 Stock Market Regulator: Banco Central del Uruguay (Área Mercado de Valores) 


\section{Endnotes}

${ }^{1}$ An extensive literature substantiates this statement, reviewed, for example, in Levine (1997) and Pagano (1993).

${ }^{2}$ For disclosure and accounting standards, see Bushman and Smith 2001, Francis et al. 2001. For dividend payouts, La Porta et al. 2000. For appraisal mechanisms, Booth 2001. For voting mechanisms, Easterbrook and Fischel 1983, and specifically for US proxy fights - Dodd and Warner 1983, Gordon and Pound 1993, Bethel and Gillan 2000. For corporate boards, see Weisbach 1988 in relation to disciplining CEOs, Charkham 1994, Warner, Watts and Wruck 1988, Kaplan 1994, Bhagat and Black 1999. For management incentive contracts, Jensen and Murphy 1990, Kaplan 1994, Hall and Liebman 1996. For ownership, see Claessens et al 2000 and many others, such as Holderness and Sheehan 1988, Franks and Mayer 2001 for Germany, Kaplan and Minton 1994 for Japan. For general investor rights, see Gompers, Ishii, and Metrick 2003. For the role of banks and large creditors, see Smith and Warner 1979, Diamond 1984 provides a theoretical basis, Gordon and Schmid 1996 for Germany, Kang and Shivdasani 1995 for Japan, Gilson 1990 for the US, Barca 1995 for Italy. For corporate control, see Jensen and Ruback 1983, Palepu 1986, Scharfstein 1988, Jensen 1986, Shleifer and Vishny 1988, Morck, Shleifer and Vishny 1990, Shleifer and Vishny 1991, Bebchuk 1994, Franks and Mayer 1996, Burkart et al. 1998, Burkart 1999, Bebchuk and Ferrell 2001, Goergen et al. 2005.

${ }^{3}$ Major studies here include: Beny (1999) on insider trading laws; Bubnova (2000) on bond markets regulation and spreads; Carlin and Mayer (1998) on laws and industrial activity, corporate and financial sector structure; DemirgucKunt and Maksimovic on law, finance, and firm growth; Himmelberg, Hubbard, and Love (2000) on investor protection laws and cost of capital; La Porta et al. (2002) on laws and corporate value, (1999) on laws and corporate ownership, (2000) on laws and CG, (2000) on laws and dividends; Licht, Goldschmidt and Schwartz (2001) on the cultural aspects of law and finance; Lombardo and Pagano (1999) on laws and the return on equity; Nenova (2001) on laws and the value of corporate control; Pistor, Raiser and Gelfer (2000) on law and finance in transition economies; and Rajan and Zingales (1998) on financial dependence and growth.

${ }^{4}$ Even a simplistic view at the legal framework will amply illustrate the underlying complexity. Securities laws and regulations create and regulate the capital markets institutions such as the securities regulator and the stock exchanges. These legal provisions, as well as regulations issued by capital markets institutions, in turn provide the rules for listed companies and other capital markets participants, such as broker/dealers and asset managers. Regulations cover such issues as public offering of shares, securities trading, disclosure, tender offers, insider trading, and delisting. In addition, company laws also regulate listed companies, by specifying, inter alia, their founding documents, corporate bodies (such as the structure of their board of directors), shareholder rights and the conduct of decision-making by shareholders (e.g., via annual shareholder meetings), rules on related transactions and large asset deals, as well as some debt and liquidation matters.

5 "Law and Finance", La Porta et al. (1998), Journal of Political Economy. A regional version is provided in "Law and Finance in Transition Economies", Katharina Pistor, Matrin Raiser, and Stanislaw Gelfer, Economics of Transition, Vol 8, pp. 325-368, 2000.

${ }^{6}$ These topics are based, in part, on the following academic research: "Regulation of Entry", S. Djankov, R. La Porta, F. Lopez-de-Silanes, A. Shleifer, Quarterly Journal of Economics, February, 2002; "The Regulation of Labor" (J. Botero, S. Djankov, R. La Porta, F. Lopez-de-Silanes, A. Shleifer, Quarterly Journal of Economics, November, 2004; "Courts", S. Djankov, R. La Porta, F. Lopez-de-Silanes, A. Shleifer, Quarterly Journal of Economics, May, 2003; "Private Credit in 129 Countries" (S. Djankov, C. McLiesh, A. Shleifer, November, 2005; "The Law and Economics of Self-Dealing" (S. Djankov, R. La Porta, F. Lopez-de-Silanes, A. Shleifer, December, 2005; "Judicial Checks and Balances" R. La Porta, F. Lopez-de-Silanes, C. Pop-Eleches, A. Shleifer, Journal of Political Economy, 2004.

${ }^{7}$ Jensen 1988, Sharfstein 1988, Goergen and Renneboog 2003, Berglof et al 2003.

${ }^{8}$ The free-rider problem is developed in Grossman and Hart (1980) and Shleifer and Vishny (1986). Shleifer and Vishny (1988) show that acquisitions can actually increase agency costs when bidding controlling parties overpay for acquisitions that bring them private benefits of control (see also Roll 1986, Morck, Shleifer and Vishny 1990, Shleifer and Summers 1988, Shleifer and Vishny 2003). Finally, takeovers occur infrequently outside of the US and the UK, and entail an exorbitant cost, so they are useful in correcting only grave deviations from optimal shareholder value (Kenneth \& McConnell 1991, Morck, Shleifer and Vishny 1989).

9 Dyck and Zingales 2002, Nenova 2003. Zingales 1994 (Italy); Horner 1988 (Switzerland); Rydqvist 1993, Bergstrom and Rydqvist 1990, 1992 (Sweden); Megginson 1990 (UK); Lease, McConnell, and Mikkelson 1983, Zingales 1995 (US).

${ }^{10}$ Nenova 2000.

${ }^{11}$ Modigliani and Perotti 1997.

${ }^{12}$ LLSV 1997, Nenova 2003. The intuition is also supported in an overview paper Modigliani and Perotti 1997: Due to feedback effects of security market development, lower investor demand causes "thin trading"; the participation of smaller number of participants in the market diminishes the "search and diffusion of information"; and poor liquidity, in turn, "increases required yields and depresses prices, further discouraging financing through security 
markets". A word of caution: this hypothesis has been challenged theoretically, and therefore requires empirical testing. Gomes (2000) constructs a theoretical model based on reputation effects that explains the high levels of minority participation in emerging markets, in spite of poor investor protection. If reputation effects are strong and act as a substitute for investor protection, firm performance will not necessarily be positively correlated with better legal protections. Burkart and Panunzi (2001) propose a model where the presence of large shareholders either complements or substitutes for investor protection. In the case where investor protection and outside ownership concentration are substitutes, investor protection may have a negative effect on firm value.

${ }^{13}$ This note has used the following sources of information, in addition to the laws referenced: Eduardo Walker, "Gobierno Corporativo, Protección a los Accionistas Minoritarios y Tomas de Control," Elementos Conceptuales de la Ley de $O P A S$, Serie Documentos de Discusión No1, SVS, 2001; "Corporate Governance in 23 jurisdictions worldwide", 2002, Global Competition Review; "Mergers and Acquisitions in 29 jurisdictions worldwide", 2002; Escobar, Ricardo, Carey Cía. Ltda., 2000, Report on Corporate Governance Issues in Chile; ISSA 2002; Begg, Peter F. C., "Corporate acquisitions and mergers: a practical guide to the legal, financial, and administrative implications"; Fernandez, Jose W., Antonio Delpino, Jose Lau Dan and Rafael Diaz-Granados, Corporate Caveat Emptor: Minority Shareholder Rights in Mexico, Chile, Brazil, Venezuela and Argentina, Inter-American Law Review, Vol. 32: 2001; Alvaro Clarke, World Bank Presentation on the reform of the Chilean Takeover Market, July 2006; World Bank Chile Corporate Governance ROSC 2003.

${ }^{14}$ The relevant laws include the Tender Offer Act (\#19.705) 2000; the Securities Market Law (\#18.045), last amended Jan 1999; as well as regulations of the Chilean Securities Commission and rules of the Santiago Stock Exchange.

${ }^{15}$ A prorated offer for all stock is not required if the control premium is not substantially different from the average market price over the last 60 days, the payment is made in cash, and the stock has low liquidity. The premium is defined annually by SVS. It is currently ten percent.

${ }^{16}$ In principle, there is an issue as to the implicit hypothesis in constructing the index, since the coding assumes a certain positive or negative impact of each legal rule on minority protection. Most legal rules that make up the components of the takeover index are fairly well studied in the literature, in terms of their impact on efficiency and/or minority interests. In those cases, we tend to use the direction of the relationship as suggested by the bulk of the evidence. We discuss the evidence in all cases, and emphasize issues where the direction of the relationship may be controversial. The disclosure of the intention to take control of the corporation has not been explicitly studied, but the literature abounds with data showing the positive effect of disclosure and transparency in general on minority interests (Zingales 2004, Chen, Chen and Wei 2003, Franks and Mayer 1996).

17 Bebchuk (1994), Burkart and Panunzi (2004). Burkart and Panunzi (2006) overview the evidence comprehensively.

${ }^{18}$ In perfect markets, this would have no negative effect; in reality, following a large accumulation of shares by a controlling shareholder, liquidity may fall, prices may get depressed, and the remaining shareholders may see the value of their shares plunge on the market.

${ }^{19}$ Rossi and Volpin (2004) find that in countries with lower investor protection stocks are less popular as means of payment for takeovers (as opposed to an all-cash bid) because stocks entail a higher risk of expropriation.

${ }^{20}$ F8.1 Code.

${ }^{21}$ Zingales (2004), Chen, Chen and Wei (2003), Franks and Mayer (1996).

${ }^{22}$ In Nigeria, the law permits any method of notice, as long as the prospectus reaches the hands of all shareholders and officers of the target and the Nigerian Securities Regulator. The prospectus contains a number of items, including the identity of the bidder and his/her current ownership in the target, the total number and class of securities sought, the type and amount of consideration offered to security holders, and any past contacts, transactions, and agreements between acquirer and target. The tender offer includes information about the conditions under which the bidder will finance the acquisition of the shares, and a proof that the required funds are available. In order to ensure greater transparency of the takeover process, the regulations may require bidders' intentions regarding the future activity of the target company to be explicitly stated in the offer document. This includes staff related issues and any changes in the labor contracts, maintaining the public status of the company, changes in the management of the company and appropriation of the assets. The level of detail in the prospectus is directed to guaranteeing equal treatment to shareholders, as well as facilitating the decision-making process.

${ }^{23}$ The rules typically set a minimum length for the tender offer (20 days to a month in most countries), deemed sufficient to enable all willing shareholders to tender. The upper limit for the acceptance period (when target shareholders can tender) can vary across countries, for example 20 days for the USA, 21 days for Nigeria, 35 days for France, and 70 days for Bulgaria.

${ }^{24}$ Offer extensions are usually required if the terms of the offer are altered, or when a competing bid is announced, to permit the public to inform itself on the changes and allow adequate time for the market to react to the new conditions. Laws would provide for the inalienable right of tendering investors to withdraw their tendered shares following a change of the offer or a competing bid. Further, many legislations would limit the rights of the bidder to change the terms of an offer in progress, for example permitting only changes that are beneficial to target 
shareholders. The Chile law presented above permits bidders to only increase the offer price or the number of shares sought. In France a bidder may extend the offer by 10 days upon acquisition of $66 \%$ of the target, in order to provide a second chance to shareholders to tender their shares. US bidders may also amend the offer to give non-tendering target shareholders a subsequent offering period of 3 to 20 business days.

${ }^{25}$ Prior to that date, tendering shareholders can still withdraw their shares. In most countries, the transaction is concluded on the last day of the offer, but there are exceptions (in Nigeria, for example, offers last 21 days and the transaction is considered finalized on day 10 for all shareholders who tendered by that day). In Germany, the act of tendering finalizes the deal and shares cannot be withdrawn at all.

${ }^{26}$ In France, this is the case for exchange offers, but for cash offers bidders are allowed to trade on the open market, with the provision that should they trade at a higher price, the tender offer conditions are immediately amended to extend that price to all tendering shareholders as well. Such a provision is also available in Italy and Nigeria, for example.

27 The country regulations could provide a fair-pricing rule whereby any subsequent purchases by the bidder (or related parties) at a higher than the tender offer price would be banned, as in Malaysia or the UK, or would entitle all tendering shareholders to the premium paid, as in Germany and Lithuania (§ 11(6) Malaysia Code; City Code (UK), Rule 36.3; $\S 28.3$ German Takeover Code; $\S 17(5)$ LPTS). There may also be limitations on the quantity bought by the bidder in the open market subsequent to a tender offer, to avoid a so-called "creeping acquisition". Generally, unsuccessful offers are followed by a 12-month ban on subsequent offer attempts. Such is the case in South Africa, for example. In Hong Kong, even a person responsible for a rumor of a tender offer that subsequently is not realized is prohibited from further offer attempts for one year (\$32.1 South Africa Code; §26(1) Hong Kong Takeover Code). ${ }^{28}$ Bebchuk (1994) considers legislating appraisal rights in conjunction with a mandatory offer rule, and theoretically shows that such legislation offers the highest social efficiency framework, as compared to both a mandatory rule without appraisal rights, and a situation where neither a mandatory rule nor appraisal rights are prescribed in the law.

${ }^{29}$ This is the case in Peru, where appraisal rights do not extend to mergers, but are instead limited to changes in the nature of the business, limits of free share transferability, or a move of company headquarters abroad. Appraisal rights after a merger are especially important in situations of illiquidity, e.g. for example where the majority shareholder already owns a vast majority of the shares and is trying to take the company private. Alternatively, majority shareholders may "time" or even attempt to affect the market for the company shares with a view to driving down the price.

${ }^{30}$ This mechanism has a much wider application than allowing shareholders to exit at a fair price, and is typical in common law countries. The process is channeled through the court, and targets to solve any minority grievances.

${ }^{31}$ This is a conservative take on the effectiveness of oppressed minority recourse. The countries concerned are Ghana, Israel, Kenya, Malaysia, Nigeria, Pakistan, South Africa, and Sri Lanka, where automatic (non-judicial) appraisal rights at a fair price are not available by law, but shareholders there have access to oppressed minority redress, where one of the orders that the court may give has exactly the effect of appraisal rights.

${ }^{32}$ In addition, national legislations typically provide for a reverse rule whereby the majority owner can force minority shareholders to sell their shares, at some predetermined price which the law can regulate in terms of fairness. In China, the threshold is $90 \%$, while in Romania it is $95 \%$, and it is $98 \%$ in Switzerland. In the US, where this threshold is $85 \%$, a majority shareholder even with a lower holding may buy out the remaining shareholders if this is approved by the company's management and authorized at a shareholder meeting by $67 \%$. In Germany, the sell-out process requires convening a general meeting of shareholders, which decides on the approval of the transfer of minority shareholders' shares to the majority shareholder for adequate compensation in cash. The adequacy of the compensation is reviewed by an independent auditor. However, a 5\% minority shareholder can initiate judicial proceedings if he finds such compensation too low.

${ }_{33}^{33}$ Burkart and Panunzi (2003), Nenova (2005b).

${ }^{34}$ Poison pill plans provide for the issue of securities and their distribution to existing shareholders (in the form of dividend payment, for example) that convert into voting shares upon a change of control of the company, thus diluting the successful acquirer out of the accumulated control package of votes. A variation of the poison pill, a poison put, is the sale of options to bondholders, allowing them to sell-off bonds during a hostile takeover, so that large principal payments come due.

The most common defensive tool of Canadian companies is the shareholder rights plan. Several hundred Canadian companies have adopted rights plans. Sharehodler agreement is only required if the pill will be in force for more than 6 months. The basic mechanics of Canadian poison pills are similar to US pills, contemplating that a 'flip-in event' will occur when any person acquires a specified percentage (often 20\%) of the securities of the issuer, causing substantial dilution to the acquirer unless a 'permitted bid' is made. However, Canadian regulators will not permit a target company to use a rights plan to shield itself indefinitely, and will often have it removed at the request of the hostile bidder. Institutional investors also favor poison pills of the less potent variety. As a result, poison pills tend to be benign, providing the target board with some extra time to respond to an unsolicited offer. The more exotic pills common in the United States, including 'dead hand' pills, 'no hand' pills and 'chewable' pills have not been widely 
adopted in Canada (Bowne Securities Connect. Recent Developments in Merger \& Acquisition Regulation in Canada. March 2002).

${ }^{35}$ Greenmail and standstill agreements involve negotiations with the aggressor in order to prevent the takeover. Litigation can be used to render the target less attractive or to challenge the takeover (e.g. questioning the compliance of the bidder with disclosure rules). Pac man defense is when the target in turn mounts a tender offer for the bidder. Scorched-earth involves selling off the 'crown jewels' to make the target less attractive. Safe harbor is a tactic whereby the target acquires a highly regulated firm to make the target less attractive. Golden parachutes are large compensation payments to executive management, payable if they depart unexpectedly, and is generally not considered as effective as other tactics.

The dynamics of a hostile bid with a white knight option are as follows. In an effort to find the best takeover price for shareholders, the target company may seek a white knight, who would propose a counter-offer to the existing hostile bid. In this case, strategic and tactical issues can be very important to achieving success in a hostile bid when there is more than one logical buyer. The target company can create considerable advantages for the white knight relative to the hostile bidder, such as providing the white knight with access to confidential information that would help it better assess its gains from the takeover and increase its bid price to the full amount of the potential gains, via confidentiality and standstill agreements. The target is not required to give the hostile bidder the opportunity to match or top the white knight offer. And finally, on the example of Ontario, the target board may agree to a variety of deal protection mechanisms in a negotiated transaction with a white knight, including break-up fees and no-shop clauses, provided they are required to induce a competing bid which represents sufficiently better value for shareholders.

${ }^{36} \S 47$ a Austrian AktG, $\S 110$ Brazil Corporate Law.

${ }^{37}$ Yurtoglu, B. Burcin, Corporate Governance and Implications for Minority Shareholders in Turkey, (2001 data). Hacimahmutoglu, S., Barriers to Corporate Takeovers in Turkish Law (1998).

${ }^{38}$ A review of the recent literature can be found in Burkart and Panunzi (2006), Andrade, Mitchell and Stafford (2001), Bhagat, Shleifer and Vishny (1990). Burkart and Panunzi (2006), p. 9-11, have a detailed discussion of the existing competing hypotheses on the issue (entrenchment vs. strengthening of the target bargaining position without a strong effect on takeover chances). On balance, the empirical evidence supports the entrenchment hypothesis. One of the pieces of contradictory evidence, supporting the stronger bargaining position hypothesis, is Comment and Schwert (1995), who show that defensive takeover measures are positively associated with the takeover premium. In contrast, Subramanian (2003) examines theoretically and empirically the bargaining power hypothesis and finds no support for it.

${ }^{39}$ For example in Germany, the management board needs the approval of $75 \%$ of the AGM, either expressly following the news of the takeover threat, or up to 18 months in advance ( $\$ 33$ German Takeover Code).

To further protect minority shareholders who disagree with the shareholder meeting decision regarding the antitakeover measures, a court procedure may be available. In Italy, the anti-takeover regulations subject only certain anti-takeover tactics to the approval of a shareholder meeting ( $\$ 104$ Italy CFA). The measures that must be approved are measures aimed at increasing the cost of the offer; measures affecting the company's assets; and "disturbing" measures (i.e. tender offer on the bidder, purchase of other companies' assets to prevent the proposed offer from succeeding for antitrust reasons, golden parachutes).

${ }^{40}$ In France some, but not all, preventive anti-takeover defenses are necessarily approved by shareholders. Numerous preventive defenses can be used, as long as they comply with the rules of fairness, transparency and loyalty to shareholders. A common pre-offer tactic provides for the transfer of a sizeable or majority stake in friendly hands to a privately held holding company, thus forcing the hostile bidder to negotiate with the shareholders behind the holding company. In addition, the target company's articles of association or an extraordinary shareholders' meeting may provide for double-voting rights to attach to shares held for two years or more, thus leaving the hostile bidder with a voting minority even if he would acquire half of the target capital. Voting caps, cross-shareholdings, and shareholder agreements may also be used. Buy-backs prior to takeover can strengthen the majority share. Multiple voting shares can also be used to protect a target from takeovers: non-voting preferred shares (actions à dividende prioritaire sans droit de vote), and non-voting investment certificates (certificats d'investissement). In the latter case the corresponding voting rights are attributed to the current shareholders. Such non-voting capital may not exceed $25 \%$ of total capital, and is in practice rarely issued. Those securities can be issues also at the time of the takeover threat, doubling effectively the capital, and placing the new securities in friendly hands. This has an additional deterrent effect because a merger or other major corporate transactions require the approval by the holders of these securities.

${ }^{41}$ General Principle 7 of the City Code states that the board of the target company may not take any action which would frustrate a bona fide offer unless the approval of the shareholders in general meeting has been granted. The Rule 21 of the City Code expands this principle by stating that certain actions are (in the absence of a waiver of the Rule and except in pursuance of a contract entered into earlier or with the approval of shareholders in a general meeting) deemed to constitute frustrating action. These actions include: 
- Issuing any authorized but unissued shares

- Issuing or granting options in respect of any unissued shares (other then the granting of options in accordance with normal practice as to the timing and level, under an established target share option scheme, where the Panel will normally consent)

- Creating or issuing, or permitting the creation or issuance of, any securities carrying rights of conversion into or subscription for shares

- Selling, disposing of or acquisition of, or agreeing to sell, dispose of or acquire, assets of a material amount (generally, where the value of/consideration for the relevant assets as compared with the market capitalization of the target company is, or the operating profit attributable to the relevant assets as compared with the operating profit of the target are, $10 \%$ or more)

- Entering into contracts not in the ordinary course of business. The Panel will regard the amendment of or entering into a service contract with a target company director (or any other change to his employment terms) as falling within this category, if the new or amended contract or terms constitute an abnormal increase in that director's emoluments or a significant improvement in his terms (other than on account of a genuine promotion or new appointment).

${ }^{42}$ In other words, management is limited in its defenses to the sole tactic of finding a friendly bidder who can offer comparable terms relative to the hostile offer. This strategy leaves minority shareholders well protected. Tactics which outright block takeover bids, and leave minority shareholders out of the deal in the sole interest of protecting current controlling parties of the corporation are detrimental to minority interests and frowned upon in Canada, for example, where they would be in direct contravention of director fiduciary duties, as well as legal provisions for equal treatment of shareholders.

In addition to anti-takeover actions during the hostile takeover offer period, effective defenses can be mounted well in advance of any offers, making the company "untouchable" for hostile bidders. In the above example of Canada, the fiduciary and equal treatment provisions effectively forbid both preventive anti-takeover measures, as well as those used during the offer period. In some countries, however, the prohibitions would not extend to preventive measures, e.g. Kenya (Art. 27 (1) (a-D) Takeover Regulations).

${ }^{43}$ In many countries, a blanket prohibition exists against any actions that would frustrate the hostile tender offer (e.g. Czech Republic and Chile). Such provisions may again prove difficult for a weak court to enforce. Adding specific prohibitions to this general ban can assure better compliance and enforcement. This is the case in Bulgaria, where the law contains both the blanket provision as well as specific examples: "During the tender offer the target company cannot issue shares, rights, warrants, and other securities, which may be transferred into voting shares, cannot make agreements, which may lead to a significant alteration of its property, cannot redeem shares, and cannot take any other actions, whose purpose is to frustrate the acceptance of the offer or to create significant obstacles or additional costs to the offeror" (§ 151(4) LPOS). South Africa takeover regulation adds to this list of prohibited actions the disposal or acquisition of assets of a material amount; the conclusion of contracts not in the ordinary course of business; and the payment of dividends which are abnormal as to time and/or amount.

${ }^{44}$ Maintaining high debt levels can make it more expensive for the acquirer to service the debt, as well as limit its ability to borrow additional funds against the target company assets. Buy-backs will concentrate control further into the hands of the large shareholder, decreasing the likelihood of a successful hostile bid. During a takeover threat, the law may either forbid buy-backs altogether (Chile), or prescribe shareholder approval, or regulations could allow them only to the extent they are part of ongoing buy-back programs, as in Brazil ( $\$ 15$ CVM Resolution 358).

$45 \S 23(1)$ India takeover regulations, Rule 5 a of the Singapore Takeover Code.

$46 \S 151(4)$ Bulgaria LPOS and TO. Yet other countries allow shareholders to approve share issue during takeovers years in advance of a possible takeover threat, as in Belgium, where a 3 years advance approval is allowed. In Germany, a white squire tactic, limited to $50 \%$ of capital, is allowed with prior shareholder approval (up to 5 years). Shareholders can also authorize a waiver of pre-emptive rights so that the block of shares can be placed in friendly hands. In Chile, legislation also bans increases in target company leverage by more than $10 \%$ of its total indebtedness existing immediately prior to the launching of the offer.

${ }^{47}$ The German Takeover Act of 2000 provides for an initial authorization either by the shareholders' meeting or by the supervisory body of the company, while the Swiss Federal Stock Exchange Act forbids the management of the target company to sell or acquire assets representing more than $10 \%$ of the target's assets without the consent of the shareholders. The Chilean regulations ban asset sales of more than $5 \%$ of the total assets of the target company during the term of a tender offer, and in Pakistan, all asset sales are forbidden during a takeover (§ 14 (1a) Pakistan Takeovers Code). Asset sales to lower company value are called "scorched earth" tactics, and sales that involve the principal assets of the company, or key assets that motivate the acquirer's takeover attempt, as "crown jewels sales". ${ }^{48}$ Companies can prevent a takeover by adopting an upper limit on the votes commanded by any individual owner, e.g. $3 \%$. The acquirer then would not be able to wield a majority of the votes even after purchasing $50 \%$ of the capital. Voting caps are actively used in Switzerland, for example, and more generally in Western Europe. 
${ }^{49}$ The European Commission and Court have been waging a battle to eliminate golden shares in Europe since 2003, and have met considerable success in the UK and Spain. The EC Court of Justice didn't entirely rule out the use of "golden" shares in France, although it cast doubts on their continued effectiveness in the future. The Czech government holds a golden share in certain strategic companies (for example, utilities) that entails the right to veto certain major decisions, including business combinations.

${ }^{50}$ For example, the removal of a director requires $75 \%$ shareholder approval in Germany by law, and the bylaws can provide an even high percentage. In Spain, the company bylaws can restrict the eligibility of director candidates for board seats.

51 A company's articles of association may provide for staggered (classified) board election where only a part of the directors of the company are appointed each year instead of all at once. A staggered board election process can serve as an anti-takeover device in unfriendly takeover attempts, since it would take a raider two full election cycles before a majority of the board becomes friendly. Most company laws do not contain a specific prohibition to staggered boards. Lithuania does, for example (Company Law §32). Moreover, staggered boards can be also perceived as useful in promoting the continuing of company leadership, as the King report notes for South Africa. Staggered boards are typical in the US, for example (Bebchuk, Coates and Subramanian 2002).

${ }^{52}$ Typically, shares of a public company are freely transferable at any time. The law bans companies from imposing transfer restrictions, which would also impede the trading in such shares on a stock exchange. It may even cause the delisting of the company from the stock exchange, as in Japan. The Swiss regulations give freedom to the listed companies to limit the interest of a single shareholder in their bylaws. Many listed companies have enforced a 3\% level which applies to shareholders acting in concert, as well. In this case, the company can refuse to agree to the transfer (Vogt and Watter 1995). Transfer restrictions are allowed in Austria on registered shares, and in Belgium, and must be adopted in the bylaws.

${ }^{53}$ For example, a six-level pyramid, where at each level the controlling owner holds $51 \%$ of the shares, and $49 \%$ are held by the public, permits that owner to control the company at the bottom of the pyramid with a real financial stake of only 1.76\% (Morck, "Corporate Governance and Family Control", GCGF Discussion paper 1, fig.2).

${ }^{54}$ An especially effective cross-shareholding technique is referred to as "parking shares in subsidiaries", where a mother company deposits, say, $25 \%$ of its capital with a subsidiary. In this case, $38 \%$ of the votes are sufficient to control major corporate decisions. What is more, if the law permits the subsidiary to vote the shares of its mother company, only $25 \%$ of the shares would be sufficient to control the firm, as the remaining $25 \%$ of the votes would be under insider control via the subsidiary. Some countries, forbid cross-shareholdings (e.g. Brazil), or limit them (Italian listed firms can only cross-hold $2 \%$ of capital).

${ }_{55}^{55}$ Section 13(d)(1); Rule 13d-1(a) of 34Act.

${ }^{56}$ Schedule $13 \mathrm{D}(5 \mathrm{c})$ of 34 Act.

${ }^{57}$ Bertrand and Mullainathan 1999, Danielson and Karpoff 1998, Becht, Patrick Bolton and Röell, 2003.

${ }^{58}$ Rule 14d-(1), (2), (3), (4), (5), (6) of 34Act.

${ }^{59}$ Rule $14 \mathrm{~d}-11$ of 34 Act.

${ }^{60}$ Rule $13 \mathrm{e}-3(\mathrm{~d})$ of 34 Act.

${ }^{61}$ Danielson and Karpoff (1998) document that in the end of the 1980s, most S\&P 500 firms and a vast majority of those firms listed on the NYSE or Amex were covered by several anti-takeover devices, ranging from poison pills, supermajority amendments to state anti-takeover laws. Bebchuk, Coates, and Subramanaian (2002) examine the theoretical and empirical evidence on staggered boards, concluding that they represent a powerful anti-takeover defense measure.

${ }^{62}$ The Dyck and Zingales variable is computed by looking directly at control premia during takeovers, whereas the Nenova measure is extrapolated from the price differential of shares with multiple voting rights and those with lower or no voting rights, in dual-class companies around the world.

${ }^{63}$ It is important to highlight an alternative hypothesis proposed in Rossi and Volpin (2004), namely, that the takeover premium might not proxy for private benefits of control, but instead may capture the gain for all shareholders from control changes. The definition of their takeover premium measure fully allows such an interpretation (the bid price as a percentage of the closing price of the target four weeks before the takeover announcement). The alternative measures of Dyck and Zingales (2004) and Nenova (2003) are defined to expressly capture private benefits (Dyck and Zingales measure the ratio of the price paid for the control block and the price two days after the takeover announcement), and Nenova extrapolates the premium from the price difference between voting and non-voting shares). The extent to which the takeover premium reflects private benefits or gains for all shareholders is unresolved in the literature.

${ }^{64}$ The variable captures one-share-one-vote provisions, proxy voting by mail, blocked shares before a shareholder meeting, cumulative voting or proportional representation rules, oppressed minority mechanisms, and the percentage required to call an extraordinary shareholder meeting. 